\title{
Mapping the towns of Europe: The European towns in Braun \& Hogenberg's Town Atlas, 1572-1617
}

Cartographie des villes d'Europe: Les villes européennes dans l'Atlas des Villes de Braun et Hogenberg, 1572-1617

\section{Peter van der Krogt}

\section{OpenEdition}

Electronic version

URL: http://journals.openedition.org/belgeo/11877

DOI: 10.4000/belgeo.11877

ISSN: 2294-9135

\section{Publisher:}

National Committee of Geography of Belgium, Société Royale Belge de Géographie

\section{Printed version}

Date of publication: 31 December 2008

Number of pages: 371-398

ISSN: 1377-2368

\section{Electronic reference}

Peter van der Krogt, "Mapping the towns of Europe: The European towns in Braun \& Hogenberg's Town Atlas, 1572-1617", Belgeo [Online], 3-4 | 2008, Online since 22 May 2013, connection on 05 February 2021. URL: http://journals.openedition.org/belgeo/11877 ; DOl: https://doi.org/10.4000/ belgeo. 11877

This text was automatically generated on 5 February 2021.

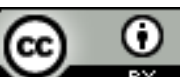

Belgeo est mis à disposition selon les termes de la licence Creative Commons Attribution 4.0 International. 


\section{Mapping the towns of Europe: The European towns in Braun \& Hogenberg's Town Atlas, 1572-1617}

Cartographie des villes d'Europe: Les villes européennes dans l'Atlas des Villes de Braun et Hogenberg, 1572-1617

Peter van der Krogt

This article is based upon the research for Koeman's Atlantes Neerlandici, vol. IV: The Town Atlases, in preparation, scheduled for publication late 2009.

\section{Introduction}

"The Civitates is one of the great books of the World, (...) a wonderful compendium of knowledge of life in Europe in the sixteenth century, (...) it gives a visual printed record of mediaeval Europe, and is one of the most valuable sources remaining to the student and historian of these periods" (R.V.Tooley) ${ }^{1}$.

Contrary to what is often thought, a great deal of travelling was done in the $16^{\text {th }}$ century. The number of travellers was greater than ever before in that century, the only exception was the number of pilgrims, which was less than in previous centuries. Salesmen, students, "tourists" and other adventurers travelled from city to city in ever larger numbers. Towns were of the most interest to travellers. Sixteenth century towns were "the seat and symbol of organized social life" and the centre of trade.

Interest in towns was as great, if not greater, than interest in countries and territories. We should therefore not be at all surprised that while Abraham Ortelius was preparing his atlas with maps of the entire world, work was being done on a publication with a similar systematic depiction and description of all the towns of the world. Ortelius published his atlas Theatrum Orbis Terrarum, in $1570^{2}$. The first part of the town description, the Civitates Orbis Terrarum, came out two years later ${ }^{3}$. 
This publication, which would ultimately consist of six parts, is usually known by the names of its authors, the "Braun and Hogenberg." The authors are Georg Braun (or Bruin) (1541-1622), a clergyman from Cologne, who was responsible for the text, and Frans Hogenberg, the most important engraver and quite likely initiator of the project. Preparation of the Civitates must have overlapped with that of Ortelius' Theatrum by two or three years. Hogenberg was working on both projects simultaneously during that period and, given his close association with Ortelius, it is difficult to believe Braun came up with the original idea. During his visit to Antwerp in 1566-68, Braun could have met both Ortelius and Hogenberg and it is possible that the idea for the Theatrum style town atlas was born in conversations between these three men. Contemporary sources regarded both works as mutually complementary.

\section{Presentation of the first volume}

The title page of the Civitates (Fig. 1) displays great stylistic similarities with that of the Theatrum. Whereas the Theatrum displays allegorical representations of the continents however, the title page of the Civitates is devoted to the origin of cities and architecture according to Greek mythology. It shows a façade with a statue of the Magna Mater (Great Mother), the source of all wisdom and knowledge in ancient Greek mythology. The title of the part is inscribed in the pedestal of this statue. The Magna Mater holds in her right hand a carpenter's level, and in her left hand a golden compass and a carpenter's square, instruments of building and construction. This symbolizes that she taught humanity the art of laying the foundations of great buildings. Below her the text reads ORNAMENT. ORB. TERR. (Ornamenta Orbis Terrarum: Embellishments of the World).

Figure 1. Title page of part 1 (Leiden, Universiteitsbibliotheek).

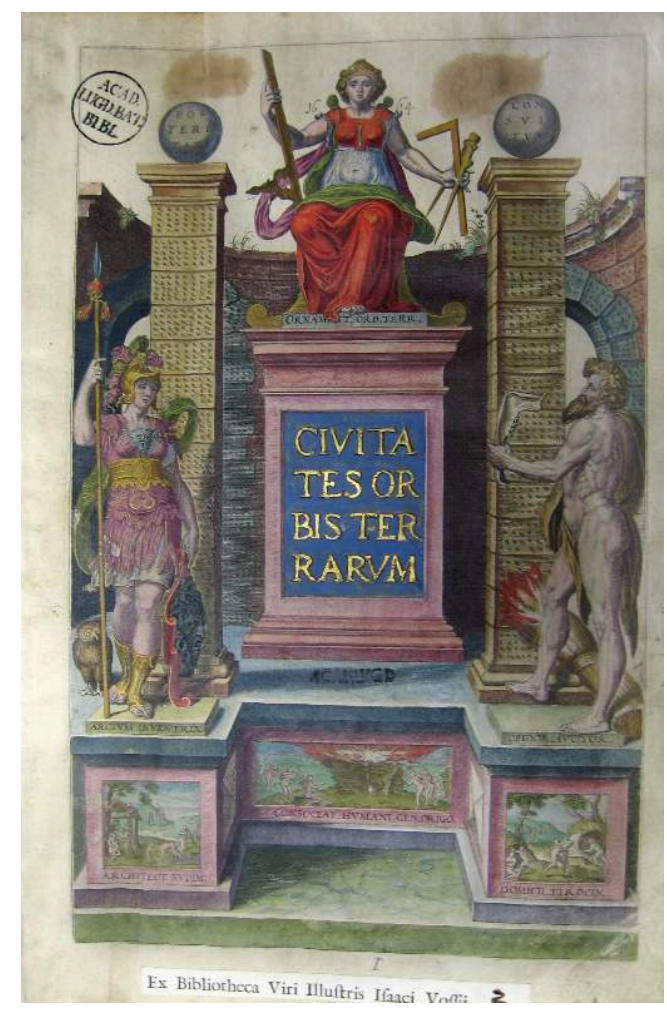


The facade with the statue is flanked by two stone columns topped by globes. On these globes the words POS | TERI | TATI and CON | SVL | TVM (In order to educate our descendants) are written. In front of the left column stands Pallas Athene (Minerva), the Greek goddess of wisdom and reason, the patron goddess of towns. She is described as ARCIVM INVENTRIX, the inventor of fortresses. On the right side stands Cain, naked except for an animal skin and in his left hand an ox's jawbone. He is described as OPPIDOR. AVCTOR: the designer of towns. As Braun explains in his foreword, Cain had built the first town, named Enoch, after murdering his brother - the ox's jawbone is the murder weapon.

The lower frieze of the structures shows three visions of the earliest stages of the settlement of mankind, illustrating the first three paragraphs of Braun's foreword (which have the same titles):

- Centre: CONSOCIAT. HVMANI GEN. ORIGO. (consociationis humani generis origo, origin of the amalgamation of mankind): mankind learns the use of fire after lightning struck a tree (Vitrivius, Architectura 2).

- Right: DOMICIL. TYROCIN. (domicilii tyrocinium, the first appearance of settlements): the undertaking of husbandry and cultivation of the fields.

- Left: ARCHITECT. RVDIM. (architecturae rudimentum, the rudiments of architecture): making rudimentary huts and building walls.

\section{The six volumes}

7 While the initial intention was to publish only one part, its success quickly gave its creators the idea to publish a second part, and subsequently expand both parts.

The second part came out in 1575. In the introduction to this second part, Braun requested those who did not find their own town in it to send in an image which could then be engraved and subsequently added to one of the two parts. This request resulted in so much material that there was enough for a third part, which was completed in 1581. A fourth part would follow in 1588, and a fifth part in 1597.

9 It would be another twenty years before the completion of the Civitates Orbis Terrarum. The sixth and final part only appeared in 1617.

10 In addition to the publications with Latin texts, versions were published with German and French texts. It must be remarked that all three editions contained exactly the same maps. The language difference concerned only the printed texts.

11 The various parts are roughly the same in dimension. Each part contains 59 sheets, except part 5 which has ten more.

12 If we count the two separately bound sheets of the double sheet maps of Rome and Jerusalem in part 4 as one, there are 361 sheets, of which four are in two sheets (the two others are Kraków and Antwerp, which always appear mounted in the atlas).

13 These 361 sheets contain 543 different images of 475 towns (which will be elaborated later on) and four other representations, namely two maps (4:25 Denmark and 4:27 Hven), a sheet of costumes of Dithmarschen (5:37), and a heraldic representation of Hainault (3:23).

\begin{tabular}{|l|l|l|}
\hline Volume & Date & Sheets Towns \\
\hline
\end{tabular}




\begin{tabular}{|l|l|l|l|}
\hline I & 1572 & 59 & 138 \\
\hline II & 1575 & 59 & 80 \\
\hline III & 1581 & 59 & 80 \\
\hline IV & 1588 & $57\left(59^{*}\right)$ & 76 \\
\hline V & 1597 & 69 & 95 \\
\hline VI & 1617 & 58 & 74 \\
\hline Total & & 361 & 543 \\
\hline *vol. 4 includes 2 double sheets & & \\
\hline
\end{tabular}

\section{Towns of the world or towns of Europe?}

Braun and Hogenberg certainly attempted to present towns of the whole world in their work. But did they actually succeed?

In the first part they were moving in the right direction: seven of the 59 sheets are devoted to non-European towns, of which a total of 21 were represented, 12 from Africa, 7 in Asia and 2 in America, meaning that $12 \%$ of the sheets, and even $15 \%$ of the towns are non-European. In part 2 another six sheets of 8 images are non-European (both approximately 10\%).

The later parts however contain no non-European towns, with the exception of the map of Jerusalem in part 4.

This means that of the 361 sheets and 543 towns in the Civitates Europae Terrarum, only 14 sheets with 30 images are non-European (of 27 towns, 3x Jerusalem and 2x Tunis, Fig. 2). So $4 \%$ of the sheets and $5 \%$ of the towns are non-European, and it is therefore easy to calculate that $96 \%$ of the sheets and $95 \%$ of the towns are European (See Fig. 3 and appendix 1 for a list of towns). 
Figure 2. Non-European towns in the Civitates Orbis Terrarum.

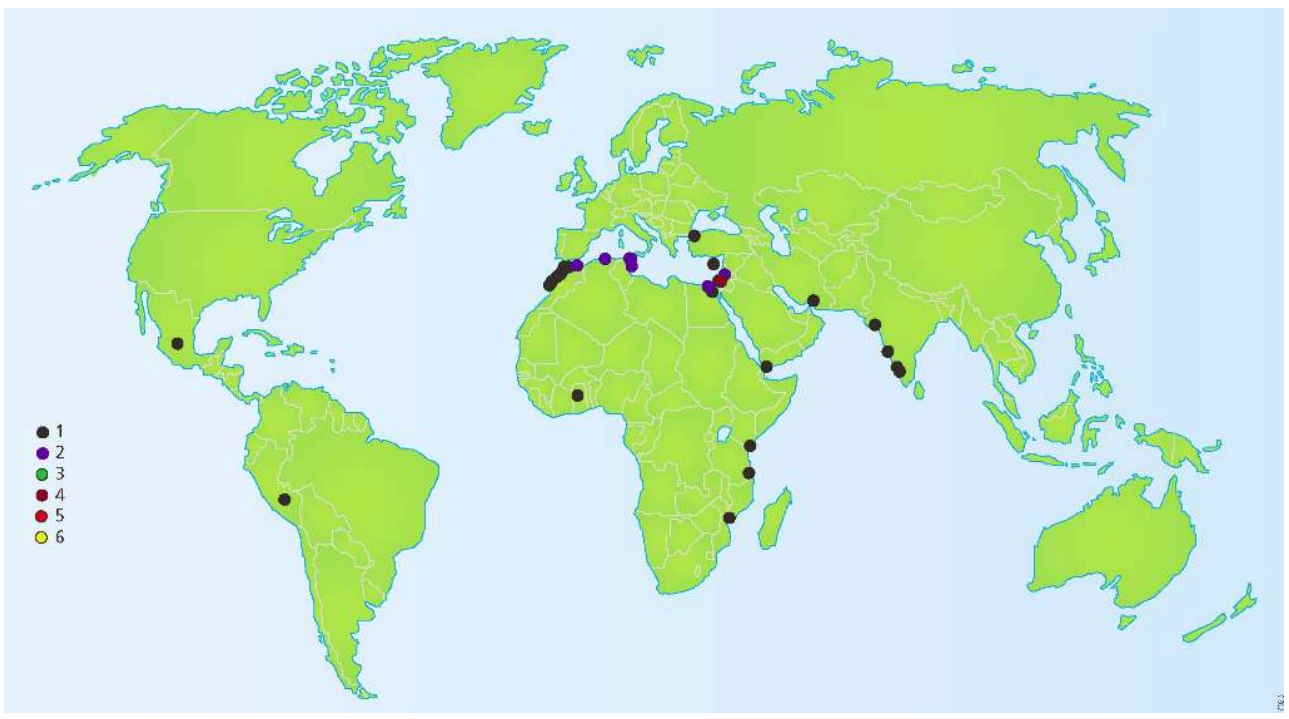

We could therefore state that the Civitates Orbis Terrarum was in reality an atlas of European towns, and could in fact have been named Civitates Europae Terrarum!

The work is not as systematically constructed as the Theatrum. The inclusion of town views or maps was determined by availability, and the desire to include as many towns as possible, rather than the systematic decision-making of a compiler. This is immediately apparent by the speed with which maps acquired by chance were included in the collection.

Moreover, each of the six parts is a distinct entity, containing town maps in a strict geographical order:

22 - The British Isles,

- Spain and Portugal,

- France,

- The Low Countries,

- Germany,

- Denmark, Sweden and Norway,

- Hungary,

- Poland, Lithuania and Muscovy,

- (Outside Europe, if any). 
Figure 3. European towns in the Civitates Orbis Terrarum.

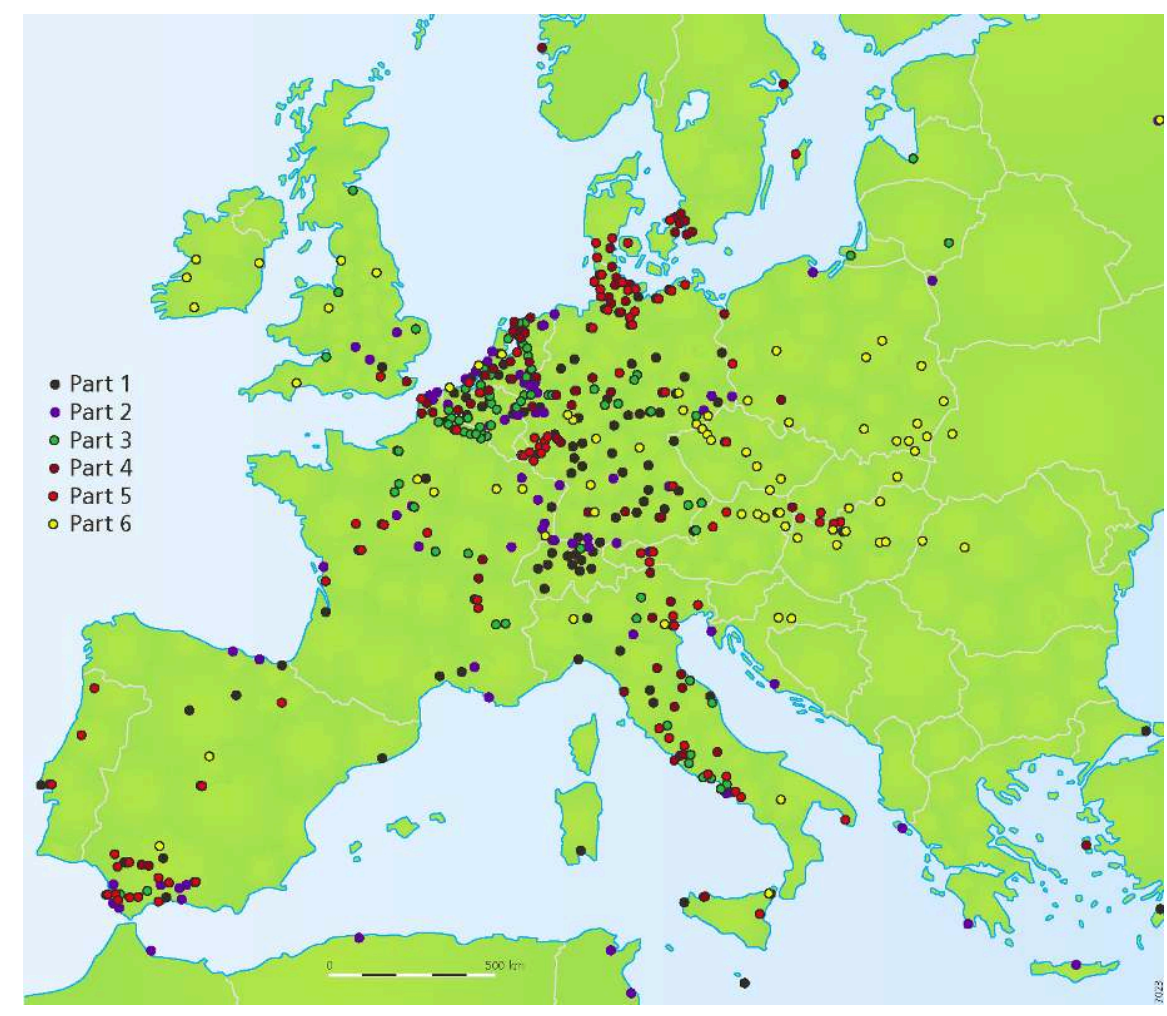

\section{New town plans}

When a more recent plan of a town was acquired, it was included in one of the later parts without changing the contents of the earlier part. In fact, the content of the parts was never changed at all.

A few examples of towns that appear in various parts:

Amsterdam (Fig. 4a-b):

The plan included in part 1 is a reduced copy of the large town plan by Cornelis Anthonisz. 1544. In part 6 a new plan was included showing the new town extensions. 
Figure 4a. Amsterdam in part 1 (Antiquariaat Forum, 't Goy-Houten).

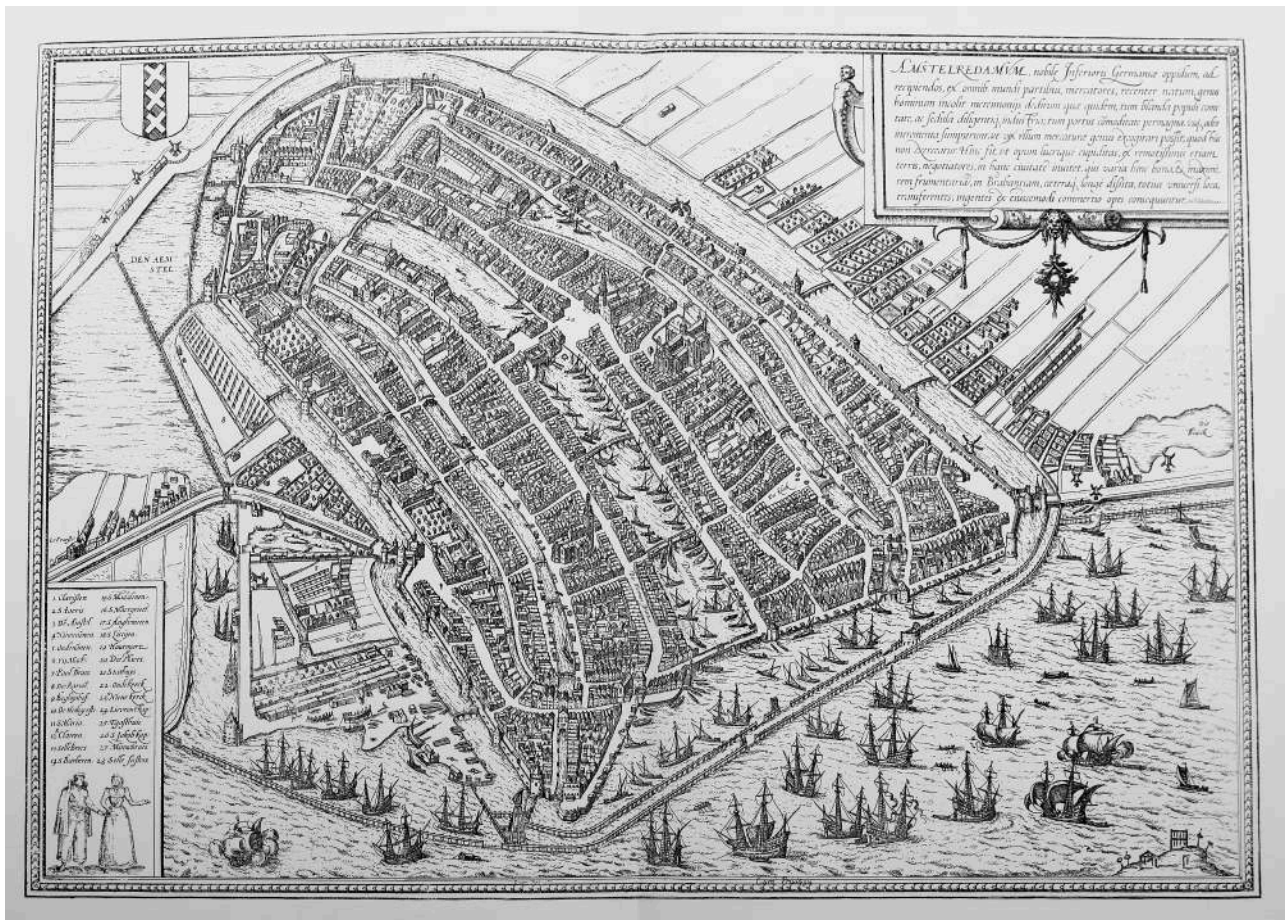

Figure 4b. Amsterdam in part 6 (Antiquariaat Forum, 't Goy-Houten).

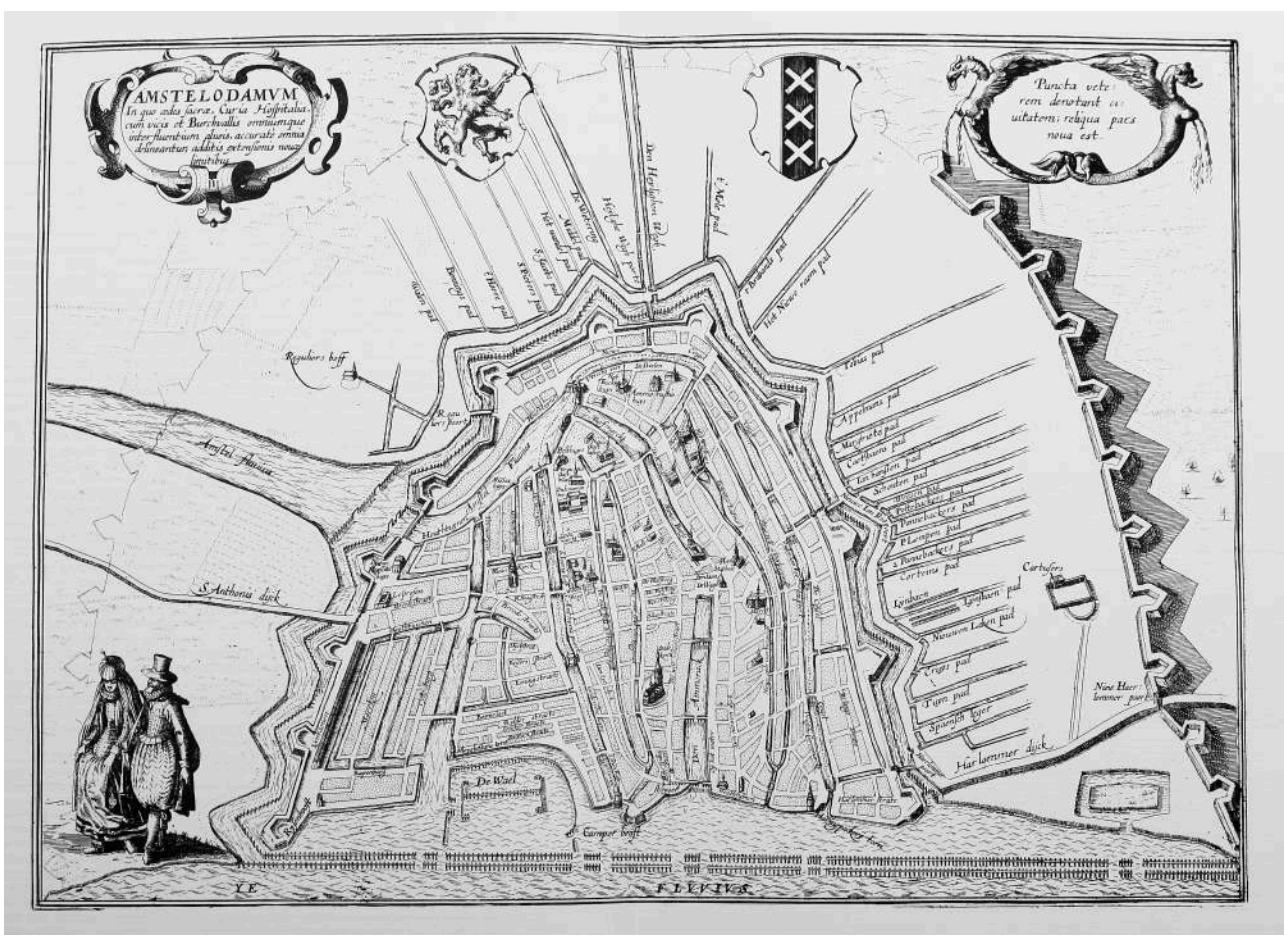

Antwerp:

The plan in part 1 - published in 1572 - already depicts the new citadel, which was completed in 1572.

27 In part 5 of 1597 it was replaced by a Joris Hoefnagel plan with roughly the same geographic representation, yet larger and more impressive in size. 
Moscow:

A primitive plan in part 2 which vaguely resembles the Kremlin, by Sigismund von Herberstein, 1547. Part 6 includes the superior plan based on a Russian map brought to Amsterdam by Isaac Massaand published by Hessel Gerritsz in 1613 .

Not only larger towns were included twice, but also the small town of Husum in Schleswig-Holstein appears twice; in part 4 on a plate together with Haderslev, and in part 5 with Tönning - the latter is definitely not an improvement.

More than 50 towns are included twice, some even three times (For example Rome and Jerusalem).

\section{Distribution of maps by country}

31 A second result of the attempt to include as many towns as possible is the uneven and apparently arbitrary division of the various countries across the various parts, in which the towns of Germany and the Netherlands in particular are overrepresented. The availability of imagery, rather than a methodical selection, therefore seemed to be the criterion for inclusion in the atlas.

Let us have a look at how the maps are divided in each part over the various countries:

Initially, in part 1 , we see a concentration of towns in the German states and the Netherlands.

In part 2 we see mostly the addition of towns in the Netherlands and the border regions of the Holy Roman Empire. Notable is also the concentration of towns in Andalucía.

Part 3 also displays an increase in the density of towns in the Netherlands, for which the work of Jacob van Deventer, who passed away in Cologne in 1574, was utilized. Various Italian towns have also been added. Notable is the row of towns in the centre of Germany. It seems as if someone has travelled from Cologne to Dresden, collecting town maps along the way!

Part 4 displays the same picture as part 3, with a particular concentration of towns in Schleswig-Holstein and around Copenhagen. For the towns in the Netherlands, the work of Jacob van Deventer has again been used.

of particular note in part 5 is the concentration of towns in Northern Germany, along the Moselle and again in Andalucía.

The concluding volume, part 6 shows the most peculiar picture. The main intention of this part seems to be to depict towns in the Eastern part of Central Europe. This is closely linked to the interest in the area at that time, fuelled by the Ottoman Wars. It is because of this that many of the sheets in part 6 are in fact more images of sieges than "true" town depictions.

If we combine everything into one overall picture, we see that the towns depicted are mainly those of the Netherlands, the Holy Roman Empire, Central Italy and Andalucía. The British Isles, France and the rest of Spain are markedly underrepresented.

Rather than teaching us what the actual objective of Braun and Hogenberg was, this division of towns tells us more about the availability of town maps in Cologne and Antwerp around 1600. 


\section{Various types of town representations}

36 A large number of town views were made by the well-known topographic illustrator Joris Hoefnagel (63 town views over six parts, of which 28 are in part V). Hoefnagel made two large journeys together with Abraham Ortelius. The first of these was to Italy; there is a picture of them walking down to the river at Tivoli on 1 February 1578, and another was Andalucía. This particularly explains the high concentration of images of Andalucía.

37 A result of this method of compilation is the depiction of the towns in dissimilar ways. Some illustrations are pure landscape drawings, while others depict town profiles or plans and all manner of variations between these.

38 The main types of town illustrations:

Town plans (e.g. Fig. 5: Brussels, part 1, no. 14)

Bird's-eye view (e.g. Fig. 6: Frankfurt/M, part 1, no. 35)

Profile (e.g. Fig. 7: Dunkerque, part 2, no. 23)

Landscape (e.g. Fig. 8: Alhama de Granada, part 2, no. 3)

Battles views (e.g. Fig. 9: Tunis 1574, part 2, no. 58), mainly in part 6.

Figure 5. Example of a town plan: Brussels (Hebrew University of Jerusalem).

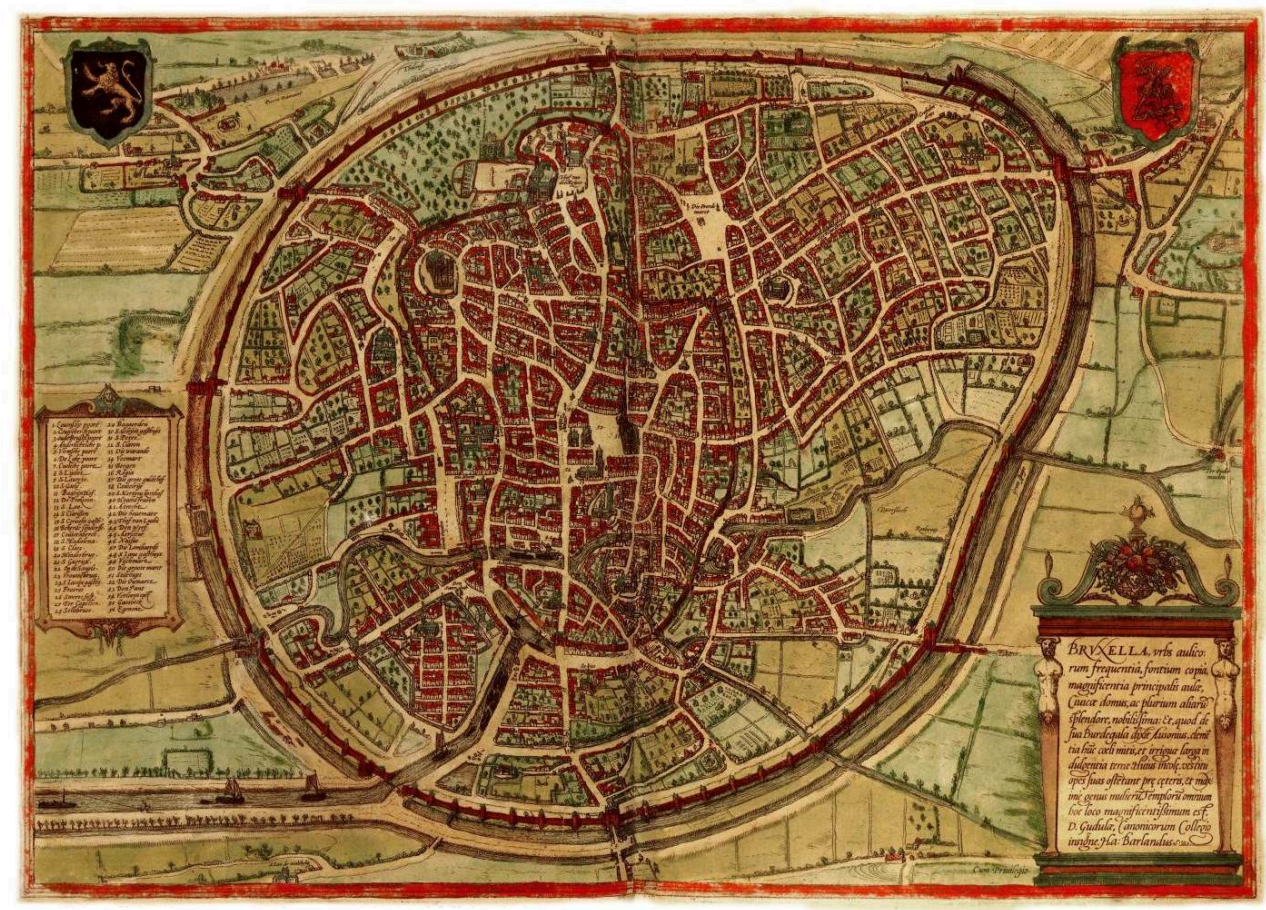


Figure 6. Example of a bird's-eye view: Frankfurt am Main (Hebrew University of Jerusalem).

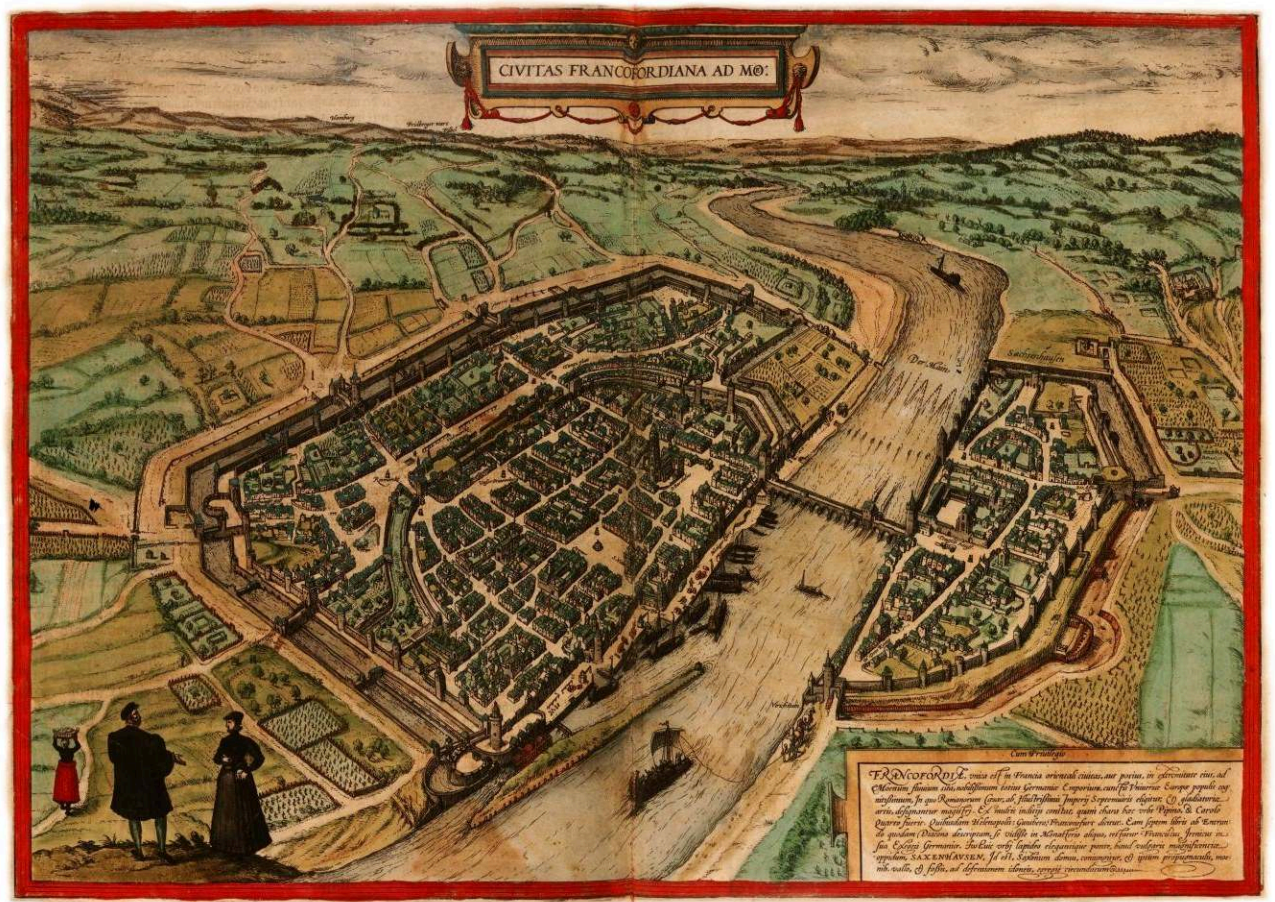

Figure 7. Example of a town profile: Dunkerque (Hebrew University of Jerusalem).

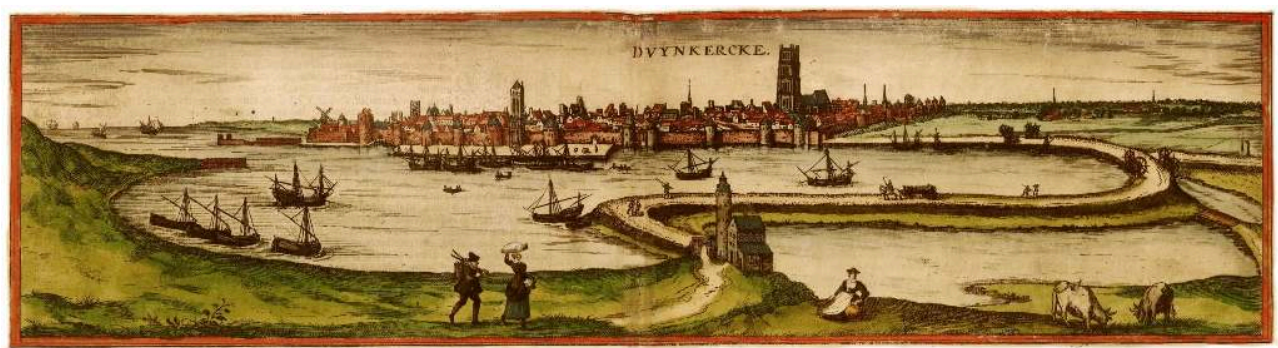


Figure 8. Example of a landscape: Alhama de Granada (Hebrew University of Jerusalem).

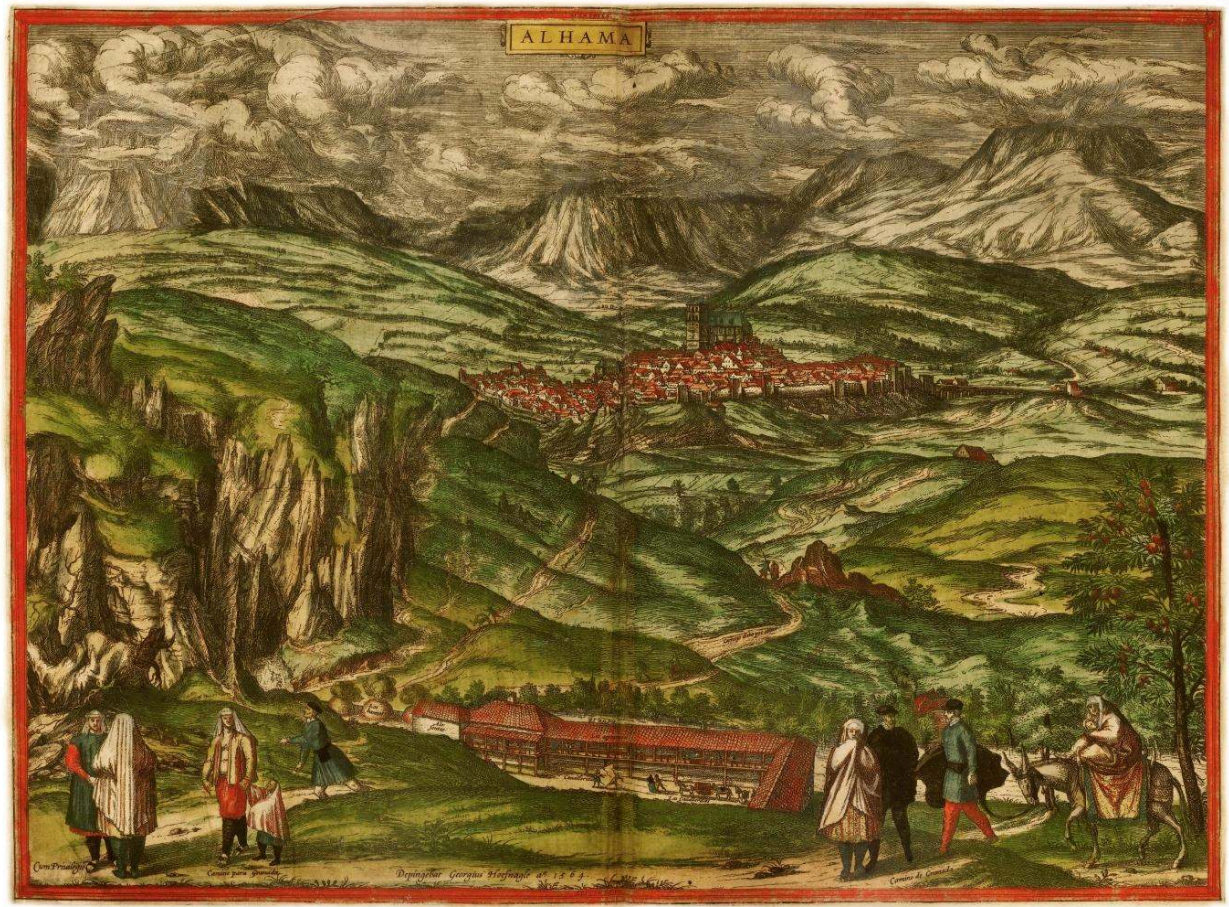

Figure 9. Example of a battle view: Tunis 1574 (Hebrew University of Jerusalem).

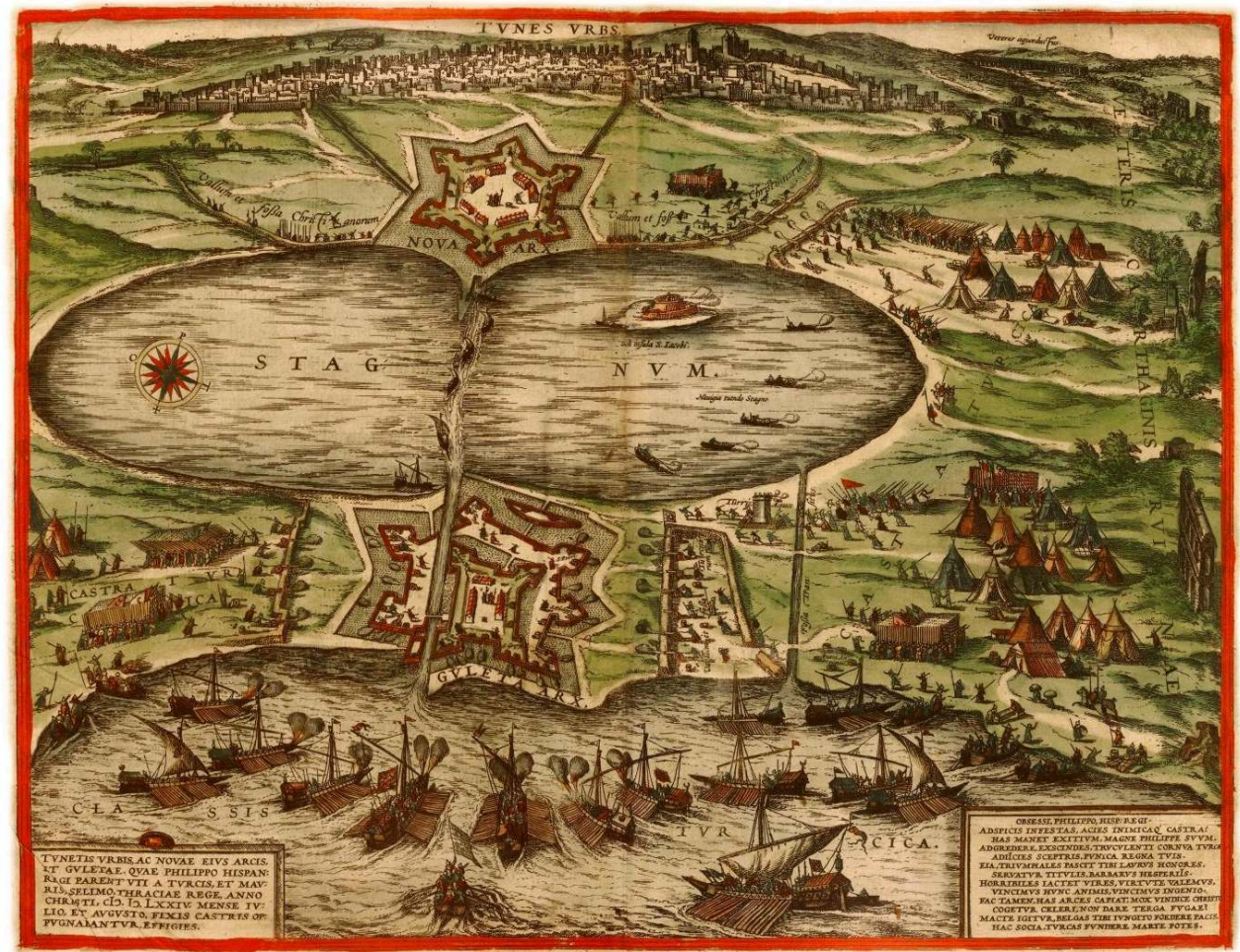


Figure 10. Panoramic view of Toledo, from part 5, no. 15 (Hebrew University of Jerusalem), and a photograph from a slightly different view angle, taken on 7 October 2007 (photo: José Manuel Azcona).
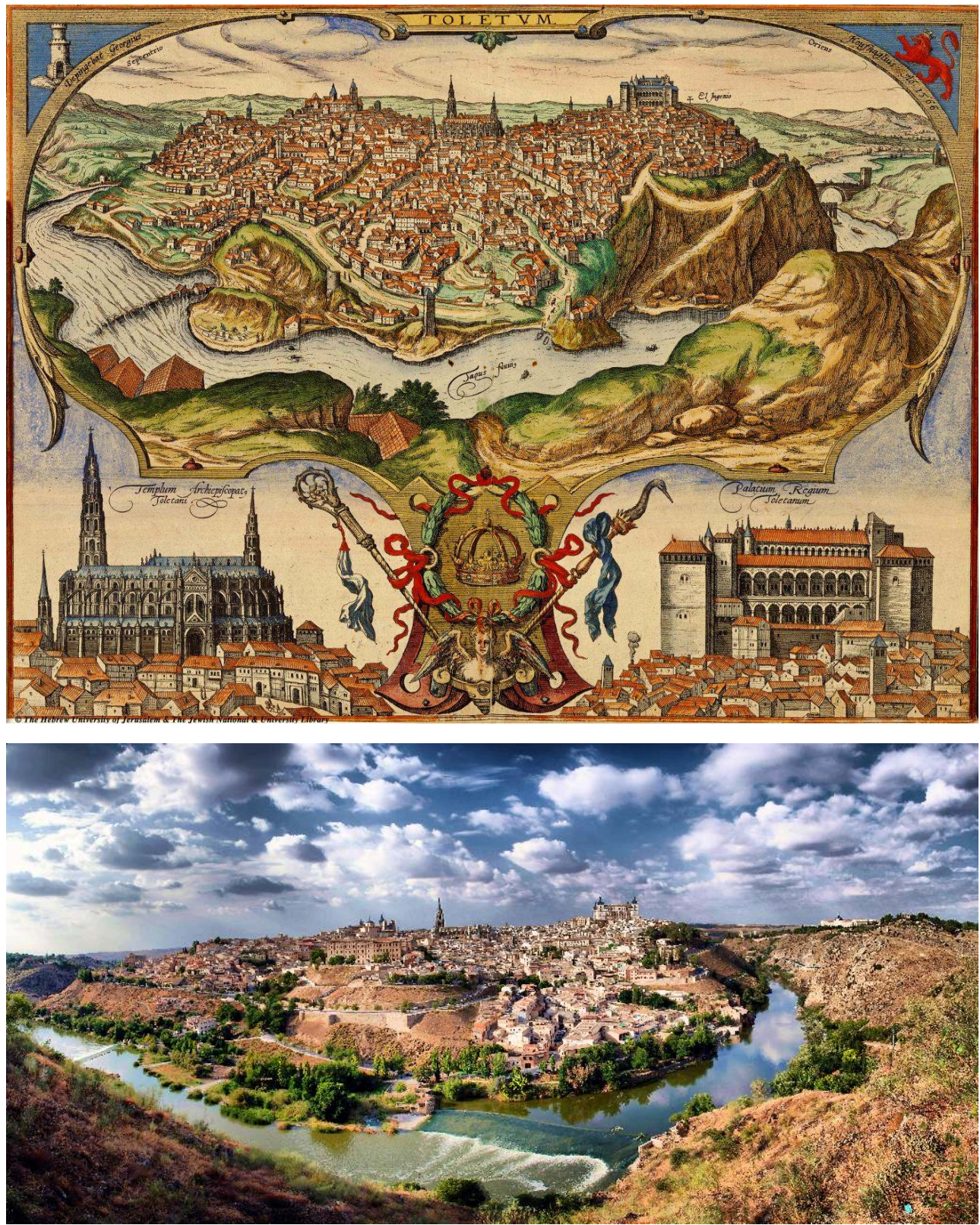

\section{How accurate are the drawings?}

No systematic research has yet been done. It goes without saying that this depends on the author. Earlier we discussed the early plan of Moscow which scarcely bears resemblance to the modern city. Yet if we look at the view of Toledo and compare it to a modern photograph from roughly the same perspective (Fig. 10), we see that the depiction of the town was surprisingly accurate.

40 Depicting a town such as Palmanova, established in 1593, is of course simple (Fig. 11). The town already makes an appearance in part 5 of the Civitates of 1596/97. It is likely 
that the original drawing by the architect was used rather than that it was mapped out again.

True research into this aspect of the town atlas has yet to be undertaken.

Figure 11. Plan of Palmanova (Antiquariaat Forum, 't Goy-Houten).

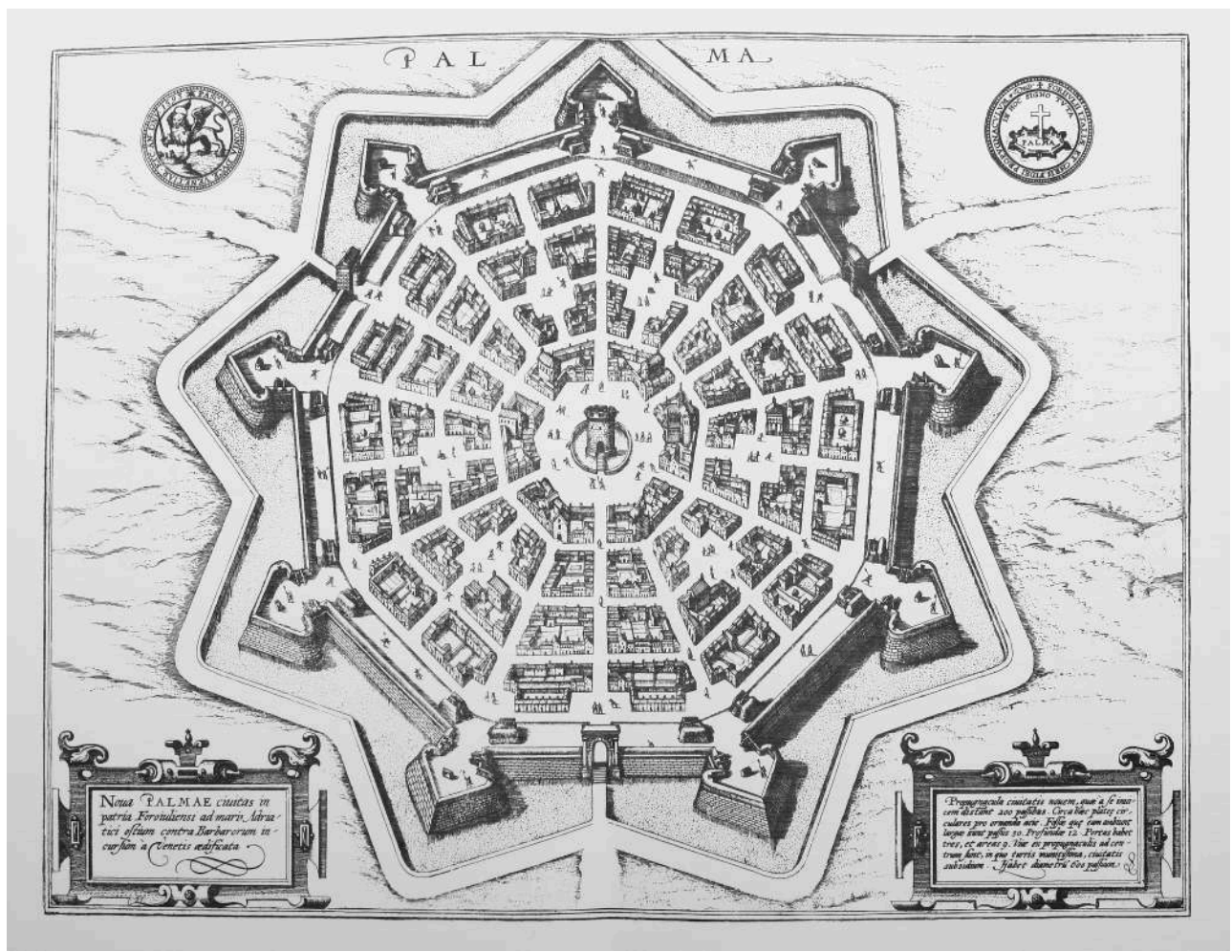

\section{Texts}

42 A very important, yet often overlooked or forgotten, factor is the back of maps. Just as Ortelius did, Braun supplied a description of the area depicted on the plan overview; in this particular case that of a town.

As an example we will reproduce and discuss here the text to the town of Delft in Holland from part 3 (no. 29; Fig. 12). In appendix 2 a transcription of the text is given in the three languages (Latin, German and French). For easy reference, the paragraphs have been numbered.

The text starts with a brief description of the name (paragraph 1). Then follow the location (2) and evolution (town rights) of the town (3), followed by the appearance of the town, its inhabitants and the economic condition (4-7). 
Figure 12. Plan of Delft (Antiquariaat Forum, 't Goy-Houten).

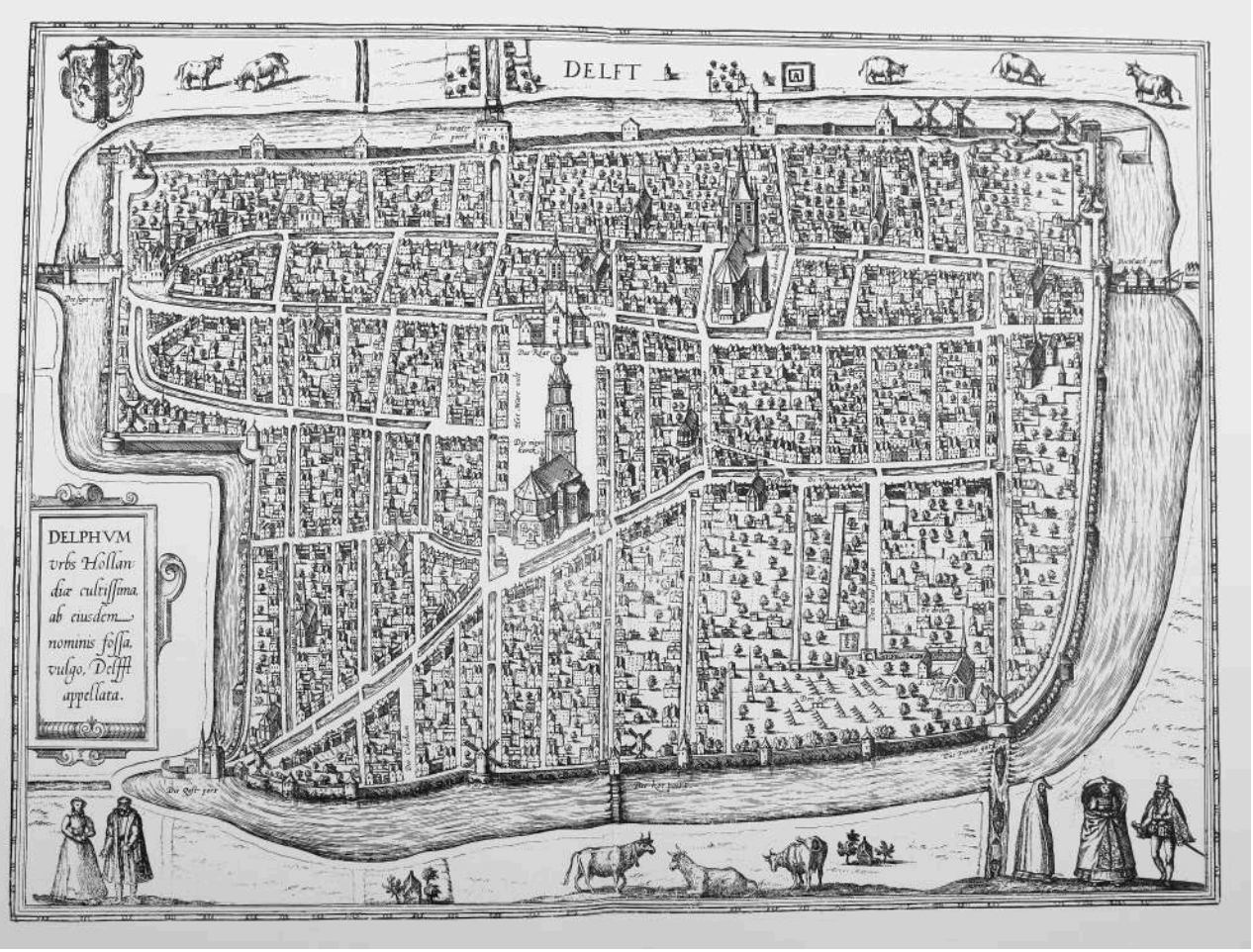

Paragraphs 8-13 give descriptions of several churches and public buildings: the two large churches the Nieuwe Kerk (New Church, founded in 1384), and the Oude Kerk (old Church, founded in the $13^{\text {th }}$ century), and St. Agatha convent, the most important of the Delft convents. Particular interest is given to the paintings in the churches.

A historical overview follows in paragraphs 14-20. Only two events are mentioned: The siege of 1359 (16) and the large town fire of 1536 (17). That of the fire includes a detailed story of a stork that was unable to bring its young to safety on time and subsequently attempted to protect them with its wings. All died in the fire (18-20).

Finally paragraphs $21-24$ give an overview of the most well-known inhabitants of the town:

David Joris (1501-1556), glass painter who gained renown as an Anabaptist and heretic. Joost Sasbout (1487-1546), Chancellor of Gelderland, descendant of a well known Delft family, with an epitaph on his grave in Arnhem.

Cornelis Musius (1500-1572), prior of Saint Agatha convent.

The first impression one would get is that a number of arbitrary facts about the geography, history, economy and inhabitants has simply been collected. The source is not cited, although it is probable that Lodovico Guicciardini's 1567 description of the Netherlands ${ }^{4}$ has been used in this case, as in the case of many other towns in the Netherlands. Further research is necessary.

\section{Costumed figures}

On all the plates in the Braun and Hogenberg town atlases a few people are illustrated in the corners (Fig. 13). These characters are clothed in the dress particular to their town. 
Figure 13. Some of the costumed figures (Hebrew University of Jerusalem).

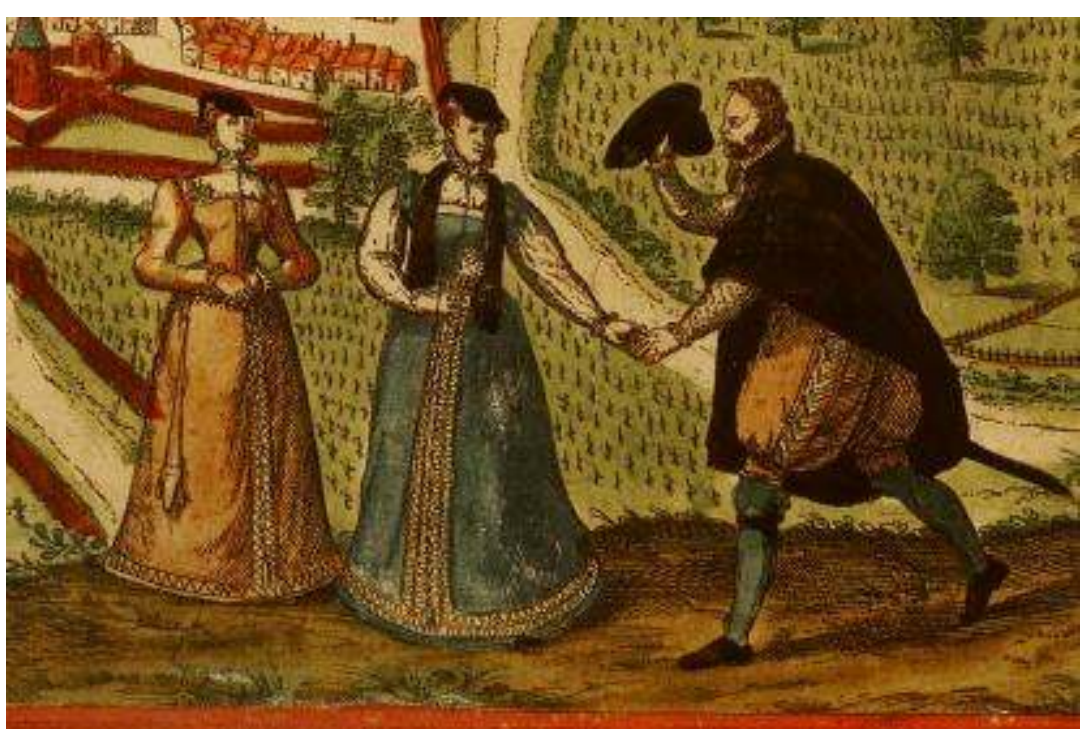

Besançon (2.16)

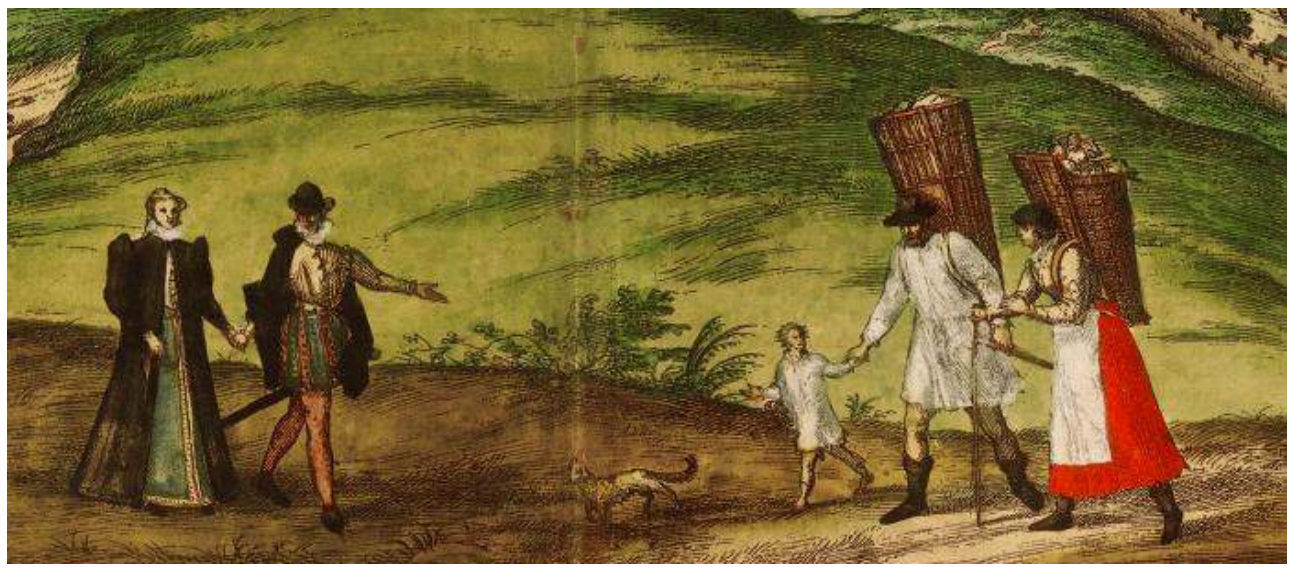

Huy (2.19)

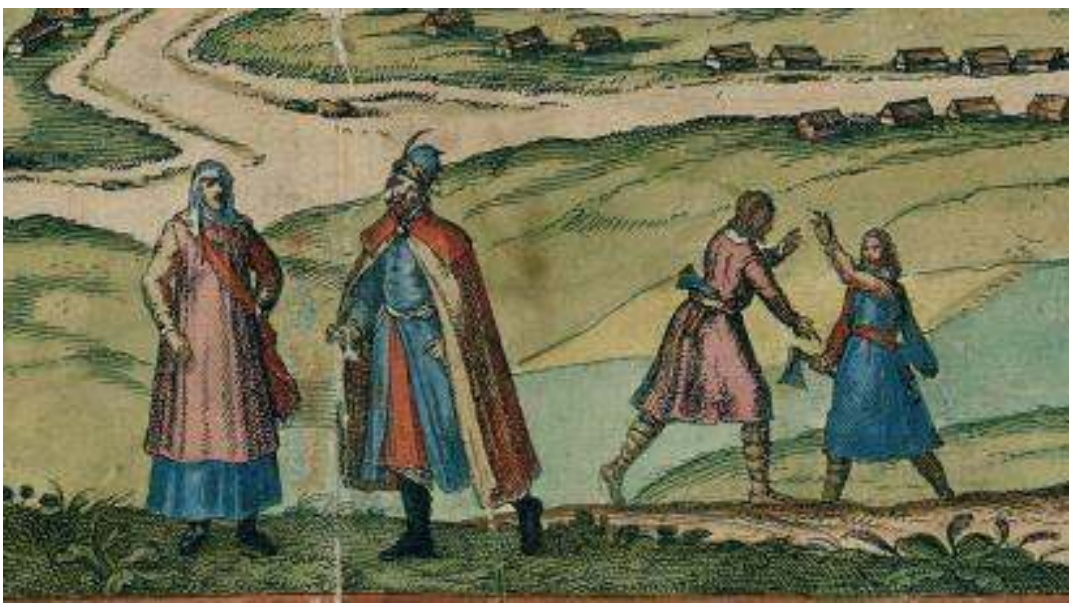

Vilnius (3.59) 


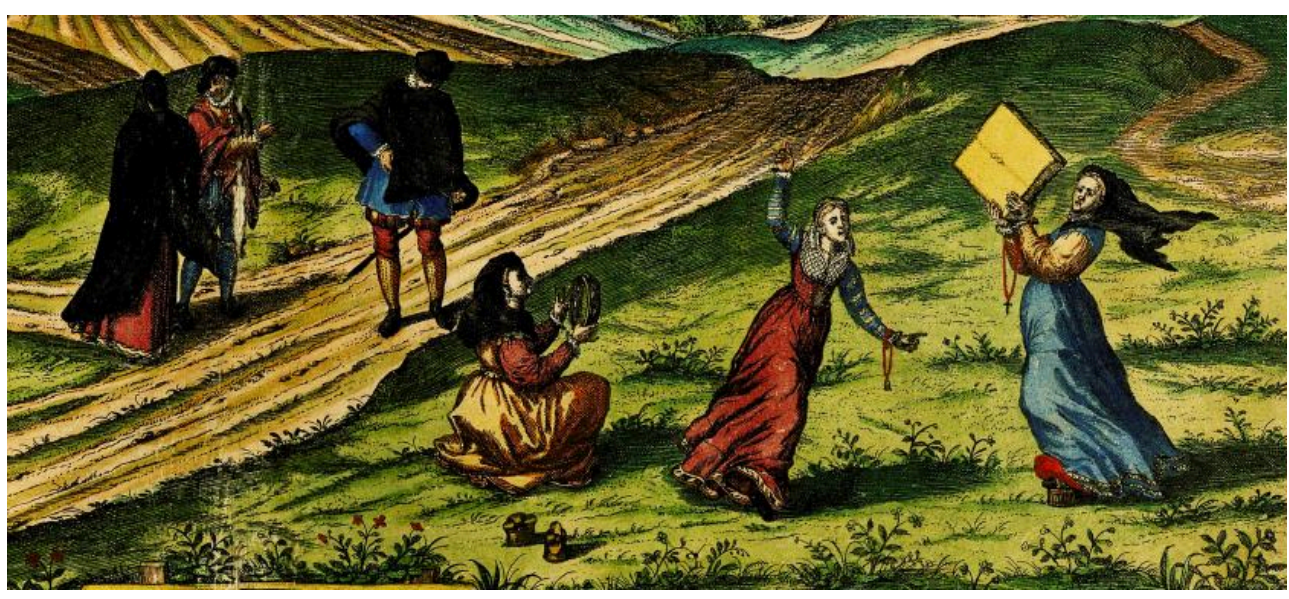

GRANADA (5.13) potential accession to the European Union, one might easily ask oneself whether
anything has truly changed in Europe's perception of Turkey over the past 450 years.

Neque verò est cur consilium hoc Christianis tandem aliquando noxium \& perniciosum fore quis putet, eò quòd primariæ ipsorum urbes fidei hostibus hac occasione contemplandæ \& discutiendæ veniant. Huic siquidem malo, quid quidem haud exiguum fore putabamus, ea ratione occurrimus, dum diversarum nationum ac gentium diversum vestiendi cultum \& habitum, utriusque tam præstantioris, quàm deterioris sexus effigies urbium simulachris appingi curavimus. Quam sanè ob causam immanissimi Turchi, qui omnino nullas, vel sculptas, vel depictas imagines ferunt, nunquam hoc opus, etiamsi maxime ipsis emolumento esset futurum, admittent.

Unnd darff sich niemandt förchten, als wen diß vornhemen den Christen einigen schaden künte brengen, drumb das ihrer vornembster Stette gelegte, den feind eröffnet wurden. Welchen vbel, welchs dan in sich nit gering were, wir mit der manier vorkhommen, weil wir aller Nationen unnd verscheidener völcker vngleiche art der kleidungen, so wol hohes als nidrigen standes bey eine jedere Stadt haben lassen setzen, Der vrsach halben, die blutdürstige Turcken, welche 
keine geschnittene oder gemahlte Bilder leiden, diß buch nummer, wie hohen nutz es ihnen auch brengen kunte, zulassen werden.

Et n'i a point pourquoy aucun doive penser que cestre nostre entreprise puisse estre quelque foys nuisible ou preiudiciable aux Chrestiens, en ce que leurs villes principales pourroyent à ceste occasion estre espiees \& visitees par les ennemis de nostre foy. Pourtant que nous avons obvié à ce mal lequel nous reputions n'estre petit, mais bien grand, \& singulierement par ce moyen, cest à sçavoir en faisant adiouster á chasque figure des villes, les effigies tant de l'homme que de la femme d'icelle ville ou pays avecques diverses guises des habits d'iceux. A cause de quoy les Turcs inhumains qui ne souffrent en aucune maniere de voir ou regarder figures quelconques, images gravees ou peintes, ne vodropyent iamais recevoir cest oeuvre quelque profit qu'il leur apportast.

\section{Conclusion}

54 I will conclude with a quote by Ronald Vere Tooley, taken from his preface to the facsimile-publication of the Braun and Hogenberg:

"The whole forms a wonderful compendium of knowledge of life in Europe in the sixteenth century. And as city growth in early times, with a few obvious exceptions, was more or less static, even further it gives a visual printed record of mediaeval Europe, and is one of the most valuable sources remaining to the student and historian of these periods."

\section{APPENDIXES}

\section{LIST OF TOWNS IN THE CIVITATES ORBIS TERRARUM}

First column: modern name of the town, listed by country (in 2008).

Second column: volume and order number (for volume 1, the number printed on the map verso. The first map is $\mathrm{A}$, the second 1 , the third 2 etc.).

Austria

Eisenstadt 6.22a

Enns 6.23

Gmunden 5.53

Innsbruck 1.40b, 2.42, 5.58

Linz 5.52

Mannersdorf $6.22 b$

Salzburg 1.31c (two versions), 3.47

Schloßberg bei Seefeld 5.59b

St. Pölten 6.24

Steinach am Brenner 5.59c 
Wien 1.41a, 6.21

Zirl im Inntal 5.59a

Belgium

Aalst 4.10

Antwerpen 1.17, 5.27

Beaumont 3.26d

Brugge 1.16 (two versions)

Brussel 1.14

Chimay 3.27c

Gent 1.15

Huy 2.19

Ieper 2.22

Leuven $1.18 \mathrm{~b}$ (two versions), 3.11

Liège 1.11

Lier 4.11

Limbourg 2.18

Mariembourg 3.27b

Mechelen 1.18c (two versions), 3.12

Mons 1.13a, 3.24

Namur 2.20, 3.32

Oostende 6.11

Philippeville 3.27a

Tienen 3.13

Tournai 4.09

Walcourt 3.27d

Belarus

Grodno 2.48

Croatia

Kostajnica 6.42

Petrinja 6.36

Porec $2.52 b$

Šibenik 2.52a

Czech republic

Brno 6.29

Cáslav 6.25a

Cheb $1.29 \mathrm{~b}$

Chomutov $6.25 \mathrm{~b}$

Louny 6.26a

Polná 6.27

Praha 1.29a, 5.49

Slany $6.26 \mathrm{~b}$

Znojmo 6.28

Denmark 
Haderslev 4.33b

Helsingør 4.26, 5.33a

København 4.28

Kolding 5.32

Odense 5.30

Ribe $5.33 b$

Tønder $5.34 \mathrm{~b}$

France

Angers 5.20b

Arras $1.13 b, 3.22$

Autun 3.10a

Avesnes 3.26c

Avignon 2.13

Bar-le-Duc 6.08

Besançon 2.16

Béthune 4.07

Blâmont 2.17

Blois 2.14

Bordeaux 1.09c

Bourbourg 2.23c

Bourges $2.10 \mathrm{~b}$

Calais 5.22

Cambrai 4.05, 5.21

Chalon-sur-Saône 4.04b

Chartres 3.08a

Châteaudun $3.08 \mathrm{~b}$

Colmar 2.36c

Douai 3.20

Dunkerque 2.23a

Fontainebleau 6.06b

Givet: Fort de Charlemont 3.26a

Gravelines 2.23b

Grenoble 3.09a

Henrichemont 5.18c

Hesdin 4.06

La Rochelle 2.11

Landrecies $3.26 \mathrm{~b}$

Lille 3.19

Lyon 1.10, 5.19a

Mâcon 4.04a

Marseille 2.12

Metz 2.15

Montpellier 1.08a (two versions)

Mulhouse 6.16b

Nancy 6.07

Nevers 3.10b

Nîmes $1.09 \mathrm{~b}$ 
Orléans 2.10a, 3.06

Paris 1.07

Poitiers $1.08 \mathrm{c}$ (two versions), 5.18a

Poitiers: Pierre Levée $5.18 \mathrm{~b}$

Romans-sur-Isère 3.09b

Rouen 1.09a, 3.07

Rouffach $2.36 \mathrm{~b}$

Saintes 5.17

Saint-Germain-en-Laye 6.06a

Saint-Omer 4.08

Strasbourg 1.33

Tours 1.08a (two versions), 5.20a

Valenciennes 3.25

Vienne 5.19b

Wissembourg 2.36a

Germany

Aachen 1.12 (two versions)

Arnsberg 4.22

Augsburg 1.39

Bad Segeberg 4.32

Bamberg 6.15

Bardowick 5.44

Barth 5.45

Bernkastel 5.25b

Bonn 2.33b

Boppard 4.24b

Braunschweig 1.23a

Bremen 1.23c, 5.41

Brühl 2.33c

Büdingen 6.13

Cochem 5.24a

Dillenburg 6.12a

Dormagen-Zons 2.33d

Dortmund $4.20 \mathrm{~b}$

Dresden $1.28 \mathrm{a}$

Duisburg 2.34b

Eckernförde 5.31

Eisleben $4.40 \mathrm{a}$

Emden 2.32

Emmerich 2.34c

Erfurt 1.25c (two versions)

Eschwege 3.39a

Essen 3.40b

Essen-Werden 3.40a

Eutin 5.34a

Flensburg 4.30a

Frankenberg/Eder 3.38 
Frankfurt am Main 1.35

Frankfurt an der Oder 1.27b (two versions)

Freiberg 2.39

Freising 1.40c

Fritzlar 3.39b

Fulda $1.25 \mathrm{e}$ (two versions)

Geldern 3.17c

Görlitz 2.45

Gotha $1.25 \mathrm{~d}$ (two versions)

Halberstadt 3.41a

Halle/Saale 5.48a

Hamburg 1.24b, 4.36 (two ver-

sions)

Hann. Münden 4.39

Heide 5.38a

Heidelberg 1.34a

Heilbronn 6.16a

Hildesheim $5.48 \mathrm{~b}$

Husum $4.33 a, 5.35 b$

Igel $5.23 \mathrm{c}$

Ingolstadt $1.40 \mathrm{~b}$

Itzehoe $4.30 \mathrm{~b}$

Jena $1.25 \mathrm{~b}$ (two versions)

Kalkar 2.35

Kassel 1.26b

Kempten 2.38

Kiel 4.34

Kleve 2.34a

Koblenz 1.36b

Köln 1.38

Konstanz 2.41a

Krempe $4.35 \mathrm{a}$

Landshut 3.45

Lauingen $4.45 \mathrm{~b}$

Leipzig 1.28b, 6.17

Lindau 1.31d (two versions)

Lippstadt 4.20a

Lübeck 1.24a

Lüneburg 1.23b, 5.42

Magdeburg 1.30 (two versions)

Mainz 1.37a

Manderscheid 5.25c

Marburg 1.26a

Marienberg 6.19

Meißen 2.44

Meldorf 5.38b

München 1.40a, 4.43

Münster 1.22a 
Münstermaifeld 5.24b

Neuss 2.33a, 4.23

Nördlingen $1.40 \mathrm{~d}$

Nürnberg 1.31a (two versions), 2.43

Oberwesel $4.24 \mathrm{a}$

Osnabrück $1.22 \mathrm{~b}$

Passau 3.46

Penig 6.20

Pfalzel 5.26b

Plön 5.36

Quedlinburg 3.41b

Ratzeburg 5.43

Regensburg 1.40e, 5.51

Rendsburg $4.35 \mathrm{~b}$

Reutlingen 6.16c

Rostock 1.27c, 5.47

Rothenburg ob der Tauber 1.36c

Saarburg 5.26a

Schleswig 4.31

Schwäbisch Hall 2.37

Siegen $6.12 b$

Soest 3.37a, 4.21

Speyer $1.34 \mathrm{~b}$

Stade $1.23 \mathrm{~d}, 5.40$

Straubing $1.40 \mathrm{f}$

Tönning 5.35a

Trier $1.36 \mathrm{a}$

Tübingen $4.40 \mathrm{~b}$

Ulm $1.31 b$ (two versions)

Warburg 3.37b

Weimar $1.25 \mathrm{a}$ (two versions), 3.42

Wesel 1.22c, 4.19

Wismar $1.27 \mathrm{~d}$ (two versions),

5.46

Wittenberg 1.27a (two states)

Worms $1.34 \mathrm{c}$

Würzburg $1.37 \mathrm{~b}$

Zell 5.25a

Zschopau 6.14

Greece

Chios 4.57

Heraklio 2.53a

Kerkyra (Corfu) 2.53b

Methoni 2.52c

Rodos $1.50 \mathrm{c}$

Hungary 
Budapest: Buda 1.41b, 6.30

Drégelypalánk 6.39

Eger 6.32

Esztergom 5.57

Györ 5.54

Pápa 6.35

Sárosd 6.38

Szolnok 6.33

Tata 6.34

Törökszentmiklos 6.37

Visegrád 5.56b

Ireland

Cork 6.03d

Dublin 6.03b

Galway 6.03a

Limerick $6.03 \mathrm{c}$

Italy

Acquapendente 5.63a

Agnano-Pozzuoli 3.57

Ancona 1.46

Bologna 4.49

Bressanone 4.45a

Cagliari 1.50a

Caiazzo 5.66

Caprarola: Palazzo Farnese 5.61

Castelnuovo di Porto 5.64b

Catania 5.69

Firenze 1.44b

Fondi 5.62

Formia 3.55

Gallipoli 5.67

Genova 1.44a

Loreto $3.51 \mathrm{~b}$

Lucca 4.50

Mantova 2.50

Messina 1.49, 6.58

Milano 1.42

Napoli 1.47

Napoli and Vesuvio 5.65

Nocera Umbra 5.64a

Novara 6.56

Orvieto $3.51 \mathrm{a}$

Ostia 4.53

Padova 6.55

Palermo 1.48c, 4.56

Palmanova 5.68 
Parma 1.48a

Perugia 4.51

Pesaro 3.50

Pozzuoli 3.56

Pozzuoli - Solfatara 3.58

Pozzuoli Bay 2.51

Rimini 4.48

Roma 1.45, 2.49, 4.54

Siena $1.48 b$

Sulmona $4.52 b$

Terracina 3.54

Tivoli 3.52

Trapani $1.48 \mathrm{~d}$

Trento 3.48

Treviso $5.63 \mathrm{~b}$

Tricarico 6.57

Urbino 4.52a

Velletri 3.53

Venezia 1.43

Venezia: Piazza San Marco

and Piazetta 5.60

Verona 3.49

Vicenza 4.47

Vittorio Veneto 4.46

Latvia

Riga 3.43b

Lithuania

Vilnius [Wilna] 3.59

Luxembourg

Luxembourg 3.16, 5.23a

Mansfeld 5.23b

Malta

Valletta $1.50 \mathrm{~b}$

Netherlands

Amersfoort 4.15

Amsterdam 1.20, 6.10

Arnhem 3.17a

Bergen op Zoom 3.14

Bolsward 4.17a

Brielle 2.27

Brouwershaven 1.21b

Delft 3.29

Den Haag 6.09 
Deventer 3.33

Dokkum $4.18 \mathrm{~b}$

Dordrecht 2.24, 3.28

Enkhuizen 3.30

Franeker 3.36b

Gennep 2.34d

Gorinchem 1.21c

Gouda 3.31b, 4.14

Groningen 1.21a, 2.31

Haarlem 2.26

Harderwijk 5.29

Harlingen 4.17c

's-Hertogenbosch 1.18a (two versions),

4.12

Hindeloopen 4.17d

IJlst 4.18d

Kampen 2.30, 3.34

Leeuwarden 3.36a

Leiden 2.25

Maastricht 2.21, 3.15

Middelburg 2.28

Nijmegen 2.29, 3.18

Roermond 3.17d

Rotterdam 3.31a, 4.13

Sloten $4.18 \mathrm{c}$

Sluis 3.21

Sneek 4.18a

Stavoren $4.17 \mathrm{~b}$

Utrecht 1.19

Venlo 3.17b

Vlissingen 5.28

Zutphen 4.16

Zwolle 3.35

Norway

Bergen 4.37

Poland

Biecz 6.50b

Gdansk 2.46

Kalwarya Zebrzydowska 6.45

Kraków 6.43, 6.44

Krosno 6.46b

Legnica $6.18 \mathrm{~b}$

Lowicz 6.51

Lublin 6.48

Nysa $6.18 \mathrm{a}$

Poznan 6.46a 
Przemysl 6.52

Sandomierz 6.50a

Swiebodzin 5.50

Szczecin 4.41 (two versions)

Warszawa 6.47

Wroclaw 4.42

Zamosc 6.53

Portugal

Braga 5.03

Cascais \& Belem 1.01b

Coimbra 5.04

Lisboa $1.01 \mathrm{a}, 5.02$

Romania

Cluj-Napoca (Kolozsvár) 6.41

Oradea (Nagyvárad) 6.40

Russia

Kaliningrad (Königsberg) 3.43a

Moskva 2.47, 6.54

Slovakia

Bratislava (Pozsony, Pressburg) 4.44

Komárno (Komárom, Komorn) 5.55

Košice (Kassa, Kaschau) 6.31

Nové Zámky (Érsekújvár,

Neuhäusl) 5.56a

Spain

Alhama de Granada 2.03

Antequera 2.04

Archidona 5.09

Ardales 5.11a

Barcelona 1.05a

Bilbao 2.08

Bornos 5.12a

Burgos 1.06a

Cádiz 1.02b, 5.05, 5.06

Cartama $5.11 \mathrm{~b}$

Ceuta $1.56 \mathrm{c}$

Conil 2.06a

Córdoba 6.05

Écija $1.05 b$

Gerena $5.08 b$

Granada 1.04, 1.05b (1st state), 5.13, 5.14

Jerez de la Frontera 2.06b

Las Alcantarillas 5.10b 
Las Cabezas de San Juan 5.10c

Lebrija 3.05a

Loja 2.07

Los Palacios 5.10a

Málaga $1.02 \mathrm{c}$

Marchena 4.03a

Osuna $4.03 b$

San Adrián 5.16

San Juan de Aznalfarache 5.08a

San Lorenzo de El Escorial:

Escorial 6.04

San Sebastian $1.06 \mathrm{~b}$

Santander 2.09

Setenil 3.05b

Sevilla 1.02a, 4.02, 5.07,

$5.08 \mathrm{c}-\mathrm{d}$

Toledo 1.03a, 5.15

Valladolid 1.03b

Vejer de la Frontera 2.05a

Vélez Málaga 2.05b

Zahara 5.12b

Switzerland

Altdorf 1.32i

Appenzell 1.32m

Baden 2.36d

Basel 1.32e, 2.40

(two versions)

Bern $1.32 \mathrm{~g}$

Glarus $1.32 \mathrm{~d}$

Luzern $1.32 \mathrm{~h}$

Sankt-Gallen 2.41b

Sarnen $1.32 b$

Schaffhausen $1.32 \mathrm{l}$

Schwyz $1.32 a$

Sion $1.37 \mathrm{c}$

Solothurn $1.32 \mathrm{k}$

Zug 1.32c

Zürich 1.32f, 3.44

Turkey

Istanbul 1.51

Ukraine

L'viv (Lemberg) 6.49

United Kingdom

Bristol 3.02 
Cambridge 2.01

Canterbury 4.01

Chester 3.03

Edinburgh 3.04

Exeter 6.01

Lancaster $6.02 \mathrm{c}$

London 1.A

Nonsuch Palace 5.01

Norwich 3.01

Oxford 2.02a

Richmond Castle 6.02d

Shrewsbury $6.02 \mathrm{~b}$

Windsor $2.02 \mathrm{~b}$

York 6.02a

Sweden

Helsingborg 4.29a

Hven 4.27

Landskrona 4.29d

Lund $4.29 \mathrm{~b}$

Malmö 4.29c

Stockholm 4.38

Visby (Gotland) 5.39

Africa

Alexandria 2.56 (two versions)

Algiers 2.59

Arzila 1.56d

Azemmour 1.57b

Cairo 1.55 (two versions)

Casablanca 1.57a

Elmina $1.54 \mathrm{~d}$

Kilwa Kisiwani $1.53 \mathrm{c}$

Mahdia 2.57b

Mombasa 1.53b

Peñon de Velez 2.57c

Safi $1.56 b$

Salé $1.56 \mathrm{e}$

Sofala $1.53 \mathrm{~d}$

Tanger $1.56 \mathrm{a}$

Tunis 2.57a, 2.58

America

Cuzco 1.58b

Mexico 1.58a

Asia

Aden 1.53a 
Calicut $1.54 \mathrm{a}$

Cannanore $1.54 \mathrm{c}$

Damascus 2.55 (two versions)

Diu $1.57 \mathrm{c}$

Famagusta 1.50d

Goa 1.57d

Hormuz $1.54 \mathrm{~b}$

Jerusalem 1.52, 2.54, 4.58-59

Plates and maps

Costumes of Dithmarsch 5.37

Denmark 4.25

Hainaut (heraldic garden) 3.23

\section{GUICCIARDINI L. (1567), LA DESCRIPTION DE TOUTS LES PAÏS BAS, ANTWERP, SILVIUS}

Text for the town of Delft (part 3, no. 29) in the Latin, German and French editions.

Latin edition

\section{DELPHIVM}

(1) DELPHIVM, Celeberrimum in Batauis oppidum, secundum in Hollandiæ Statibus locum obtinet. Gentis ipsius lingua ex frequentibus Mosæ alueis eò deductis, nomen sortitum, vulgari namque sermone, fodere, siue alueum \& fossam ducere, Delffen, indigetant.

(2) Duobus milliaribus Roterodamo, Erasmi illius doctissimi patria, vnico verò, eoque exiguo à maximo, \& venustissimo totius Europæ pago, Haga comitis distat.

(3) Conditum olim ab illo Gothofredo Lotharingiæ Duce, cognomento, Gibbo, Anno salutis M.LXXV, qui ciuitati imposuit Castrum, seu præsidium, in quo \& habitabat, cuius iam nulla extant vestigia, \& cum annis quatuor per tyrannidem Hollandico potitus Comitatu fuisset, à Theodoro, eius nominis V, legitimo Hollandiæ Comite victus, è Comitatu tandem expulsus, veruto Antvverpiæ suffossus est.

(4) Id oppidum copiosum ac lautum, valido murorum ambitu cinctum, vallo, ac propugnaculis firmum, sed \& reticulato sæpimento, muri instar, valde munitum, aqua etiam ea latitudine ambitur, quam vir, alioqui fortissimus, lapidis iactu superare haud queat.

(5) Varijs euripis atque canalibus, ad magnam civium opportunitatem passim distinctum, \& aquis mirificè instructum. Unde quemadmodum in ædium \& domesticæ supellectilis nitore atque mundicie, communi eorum sententia, qui varias mundi perlustrarunt partes, vni Holllandiæ palma conceditur: ita in nitidissima Hollandia, primas eius laudes inter omnes eiusdem territorij urbes, soli attribuunt Delphio. (6) Quò etenim pluvia frequentior, quæ alias defoedare urbes ut plurimum solet, eò venustius huius oppidi vici \& plateæ, ob situm nimirum elegantem, nitent, cum ea occasione sordes omnes ad canales \& aquas, peroportune transmittat.

(7) Inhabitatores ipsi peculiari quadam, \& innata humanitate, civilitate morum, ac politia culti, Mercaturam \& Lanificium exercent, sapidam ac præstantem cerevisiam coquunt, remotisque in locis distrahunt: unde eius opificij, imò negociationis dixeris, 
cives sunt opulentissimi.

(8) Aedificia tam publica quam privata, sumptuosa \& superba.

(9) Atque ut prius ab his, quæ religioni nuncupata, exordiar, Primaria urbis Ecclesia, quam novam appellitant, cuivis prima sunt posita fundamenta M.CCC.LVI salutis anno, Basilica augusta \& elegans, D. Ursulæ sacra, præstantissimis summorum artificum Hemskerchii nimirum, Francisci Flori, Antonij Blocklandi, \& Petri cognomento Longi, picturis eleganter oranata, eleganti turri remitissimè visendam exhibet.

(10) Veterem autem ecclesiam D. Hyppolito dicatam, Hembskerchij, \& M. Ioannis Schorimanus, Ultraiectini quondam Canonici, cuivis visendæ in tota passim Hoollandia ; conspiciuntur picturæ, decenter exornant.

(11) Sed, quid de S. Agathæ coenobio referam? Sive enim structurarum magnificentiam (Principes namque viros, hospitio frequenter excepit) sive redituum \& annui census opulentiam, sive templi ornatum consideres, singula hæc, narrationis longè superant fidem. Eius namque virginei coetus Basilica, propter arctam Musij, eiusdem coenobij Præfecti vigilantissimi, \& Hembskerchij Harlemicolæ, illius quidem poêtæ clarissimi, huius verò pictoris celeberrimi, amicitiam, tota intus exquisitissimis picturis contecta, vestitaque erat.

(12) Spaciosum \& amplissimum est oppidi forum, cui, sicut Orientali in latere, per augusta \& præcipua Basilica, ita in occiduo senatoria domus, splendore longè maximo existit, præcelsa turri, \& in ea campanaria harmonia, conspicua, qua celebrium nuptiarum tempore, dum itidem forum nundinis hebdomadarijs frequentatur, lepida exercetur musica, quæ, uti epulantes in nuptijs, iucundissima suavitate exhilarat, ita vendentes, ementesque in forum allicere videtur.

(13) In suburbijs, omnis generis mercatura exercetur, domus sunt elegantes, hospitia ampla, que hospites, si re pecuniaria bellè instructi, lautissimè excipiant.

(14) Atque hæc blandientis fortunæ Delphensium, arcta \& compendiosa sit quædam narratio.

(15) Verum, cum nihil sub sole firmum, nihil constans, ac stabile: infausti subinde casus, eius fælicitatem interruperunt, dum rabidi Martis, \& implacabilis Vulcani furores, præclaram hanc urbem turpiter quandoque deformarunt.

(16) Ab Adelberto siquidem Bavaro vicesimo sexto Hollandiæ Comite, gravi obsidione pressa, privilegijs, murisque privatur. Sed à subsequenti statim Comite, Guilielmo Bavariæ, privilegia civica ipsis restituta sunt, \& moenia restaurata, ob acquisitam, Delphensium ope, contra Frisones victoriam.

(17) Anno deinde M.LXXXVI* in Maio, ipso S. Crucis die, statim à prandio, miserando infortunio hæc urbs circumvenitur. In ea.enimcum improviso casu gravissimum erupisset incendium, utramque Parochialem ecclesiam, novam \& veterem, Xenodochia, \& ducentos, ultra mille, focos, absumpsit, vix quinta urbis parte remanente illæsa.

(18) Mirabile verò, quod in tanto illo incendio à pluribus conspectum, neque olim fortasse à primis illis naturæ observatoribus, neque ab ijs, qui nostro seculo vixerunt, alibi animadversum fuit. Plinius quidem \& alij, non postremæ notæ auctores, ceu rem magnam, \& observatu imprimis (uti re vera est) dignam tradunt, ciconiarum sobolem, ætate graves, \& ad cibum quærendum viribus defectos parentes fovere, atque alere: sed, quod ab ijsdem animalibus exemplum id temporis editum fuit, \& maius quiddam est, \& maiore admiratione dignum.

(19) Ad hanc urbem, loco ad huiusmodi volucrium pastum perquàm idoneo sitam, magnæ quotannis earum, cohortes nidificaturæ convolant.

(20) Incidit autem hæc incendij calamitas in diem Maij tertium, quo tempore ciconiolae 
iam grandiusculæ sunt. A multis igitur illic visum ac observatum fuit, parentes, cum flammam \& natis, \& nidis instare cernerent, primum omni ope adnixas, ut natos flammis eriperent, cum deinde corporis mole graviores gestare non possent, eos alis, quantum poterant, contexisse, adversusque incendia \& flammas propugnasse ; ad extremum, tanquam superstites eis esse recusarent ; incendio unà consumptas, mori sustinisse.

(21) Hinc oriundus erat scelus ille David Georg, abominabilis conditor sectæ, de qua plura in Indice.

(22) Quod quidem in huius urbis contumeliam minimè narratum putandum; cum vicissim viros honorandos ac suspiciendos plurimos genuerit, quales imprimis fuerunt Aegidius Poëta, \& Ioannes Grammaticus. Multo verò omnium præstantissimus Iodocus Sasboutius, clarissimus utriusque Iuris Doctor, Cancellariæ Geldricae Præses à Carolo V constitutus, \& simul Poëta elegantissimus, cum ad extremum iam vitæ appropinquaret, hoc sibi ipse Epitaphium conscripsit, quod hodieque in eius tumulo, apud Arnemium primario in templo conspicuum, huc, propter elegantiam \& pietatem, adscribere visum est.

(23) Siste gradum: quod es, ipse sui, fortaßis eris cras

Quod sum, cadauer putridum.

Olim Iodocus eram Sasbout: me misit in auras

Delft, clara pars Batavioe.

Ter denis patrice causas decidimus annis,

Pars consili haud ingloria,

Deinde \& pacatis Proses ius Coesare Gueldris

Dixi, iubente Carolo.

Quid tituli? quid opes? quid nunc prudentioe prodest?

Mors summa miscet inferis.

Sola manet virtus homini post funera, solam,

Dum vivis, hanc ama.

(24) Eadem etiam civitas inter cæteros eruditione præstantes viros habuit, Cornelium Mussium, virginei sodalitij ad S. Agatham, Rectorem, virum rara morum probitate, Theologum insignem, Poëtam elegantissimum, \& virum Dei, infoelici hoc nostro ævo, martyrem.

German text

\section{DELFFT}

(1) Delfft ein weitberümbte statt in Holland, welche den andern grad under den Stathen in Hollandt besitzt, hat nach der spraach desselben volcks den namen von den vilen Teichen, so auß der Maaß dahin geleit worden, bekommen. Dann graben, und einen Teich oder Grube auffwerffen, heissen sie daselbst in gemeiner spraach Delffen.

(2) Sie ligt zwo meil von Rotterdamm, deß hochgelehrten Erasmi Roterodami heimet: aber nur eine unnd darzu kleine meil von dem grössesten und aller lüstigsten Dorff in gantz Europa, Graffen Hagh.

(3) Ist vorzeiten im jar 1075 durch Gothifredum den Hertzogen von Lothringen mit dem zunamen Der Hubbericht, erbawet worden, welcher auch ein Schloß oder Festung darin gebawt, auff welchem er gewohnt, dessen man auch noch etliche anzeigungen findt: und nach dem eer die Graffschafft Holland vier jar lang mit gewalt innen gehabt, ist er darnach von Graff Theodoro dem fünfften dieses namens und rechten Erben Hollands 
uberwunden, endlich auß der Graffschafft vertriben, und zu Antorff durchspitzt worden.

(4) Diese volckreiche und herliche statt mit starcken Ringmauren umbgeben, darzu nicht allein mit einem Wall und Bastey befestigt, sonder auch mit einem geflöchten Zaun, wie mit einer Mauren, wol verwart, ja auch mit so einem breiten Wassergraben umbringt, daß ein starcxker mann mit einem Stein kaum hinüber werffen kan.

(5) Darneben ist sie auch mit vielen Wasserströmen und Känelen, gantz füglich vor die bürgerschafft, underscheiden, und darumb mit Wasser wunder wol versorgty: daher dann geschicht, daß, wie mit einheiliger zusammen stimmung aller deren, so viel örter der Welt durchwandert haben, dem Hollandt allein, der glantz und reinigkeit im Haußrhat zu halten zugeschrieben wirt, also die Holländer selbst den vornembsten theil solches lobs under allen stätten desselben gebieths der statt Delfft allein zumessen.

(6) Dann je öffter es regnet, welches andere stätt gemeiniglich pflegt wüst zu machen, je säuberer die Gassen in dieser Statt glentzen, welches dann ihrer schönen gelegenheit halben geschicht, sintemal sie also alle unsauberkeit fein in obgedachte Wasserkänel tragen.

(7) Die inwohner sind sonderlich und von natur leutselig, höfflich und bescheiden: sie treiben Kauffmanschafft und Wolweck: bräwen wolschmeckend und köstlich Bier, und verhandeln dasselbige in fernen landen, daher dann die bürger, so diß handweck, oder viel mehr diese Kauffmanscahft uben, die aller reichsten sind.

(8) Die Häuser drinn, so wol die gemeine, als auch die eigene, sind köstlich und prächtig gebawt.

(9) Und damit ich erstlich an denen, so die Religion belangen, anfahe zu reden, ist die Haubtkirch daselbst, welche sie die Newe heissen, der Fundament im jar 1356. erst gelegt worden, eine grosse, herliche und schöne Kirch, im namen S. Ursulae erbawet, und mit gewaltig schönem Bildwerck der aller künstrichsten meister, als Hemskirchij, Francisci Flori, Antonij Blochland und Petri Langen gantz herlich geziert: läst sich auch mit einem hübschen Thorn von weitem sehen.

(10) Die alte Kirch, nemlich S. Hyppoliti, wirt auch durch M. Joh. Schori, welcher vorzeiten ein Canonicus zu Utrecht gewesen, dessen Gemähl man auch hin und wider in gantz Holland findt, und durch obgemeldten Hemskirchij handarbeit gantz hofflich illustriert.

(11) Was soll ich von S. Agathæ closter sagen? Dann ob du gleich seinen herlichen baw, (singemal es offtermals Fürsten beherberget) oder abder seine Renthen, und järlich einkommens, oder auch die zierde seiner kirchen betrachtest, sind doch alle diese ding und ein jedes insonderheit, grösser, dann gläubwirdig dauon zu sagen ist. Dann die krich desselbigen Jungfrawclosters, war von wegen ger grossen freundtschafft zwischen Musio, dem vorständer oder Abt gemelten Closters, und zwischen Hemskirchio wonhanfftig zu Harlem, deren jener ein weitberühmbter Poet, dieser aber ein namhaffter Mahler ist, inwendig mit gar alten Gemählen gantz bedeckt und getäffelt.

(12) Es hat einen grossen und sehr weiten Marckt in dieser statt, und wie demselbigen auff der seiten gegen morgen die herliche haubtkirch grosse zierd anlegt, also zieret ihn auch auff der seiten gegen abendt das Rahthauß uber auß herlich, und solches von wegen seines herlichen Thorns und Musick seiner Glocken darauff, welche zu statlichen Hochzeiten, wenn ohn das der Marckt deß Wochenmarcks halben voller volcks ist, lieblich darauff gehalten wirt: und wie sie mit irem lieblichen gethön die 
Hochzeitleut uber der mahlzeit frölich macht, also scheinets auch, als ob sie die käuffer und verkäuffer gleichfals auff den Marckt herzu locke.

(13) In der Vorstatt treibt man auch allerley kauffmanschafft, hat schöne Häuser drinn, und grosse Herbergen, welche die Gäst, wenn sie nur wol gelt haben, herlich auffnemen und tracieren.

(14) Diß sey also kürtzlich von dem glückseligen standt der Delffter gesagt.

(15) Aber wie nichts under der Sonnen durchaus beständig und standhafftig ist, also haben auch jederweil etliche unglückliche zufäll diese ire glückseligkeit verstörret, da nemlich die unsinnige kriegslauff und Brandt diese herliche statt schändtlich mißhandelt und verwüstet.

(16) Dann durch Adelbertum von Beyern, den sechszehenden Graffen in Holland, ist sie mit einer harten belägerung bedrungen, darzu irer Freiheiten und Mauren beraubt worden, aber von Guilielmo auß Beyern, den nechst folgenden Graffen, von wegen deß Siegs, so er mit der Delffter hülff wider die Friesen erlangt, alles wider bekommen. (17) Darnach anno $1086^{* *}$ ist sie im Meyen, eben auff den H. Creutz tag, bald nach den morgen Imbß, mit einem erbärmlichen unglück uberfallen worden. Dann als da unversehens ein groß und schwerlich Fewr entstanden, hat es beide Pfarkirchen, die newe und alte, mit den Spitälen, sampt tausent und zweyhundert Fewrstetten verzehrt, daß also kaum der fünffte theil der statt unbeschädigt blieben.

(18) Es hat sich aber mitlerweil ein wunder ding zugetragen, welches viel leut in solchen grossen Brandt gesehen, unnd villeicht vorzeiten weder von den ersten erkündigern der Natur, noch von denen, die zu unser zeit gelebt, anderswo vermerckt worden. Plinius zwar, und andere ansehnliche Scribenten mehr, schreiben, als sey es ein groß ding, und (wie es dann auch in der warheit ist, vornemlich wol zu mercken), nemlich, daß die junge Storcken ire Eltern, wenn sie alters halben schwach und nun mehr ire nahrung zu suchen krafftloß worden, beschirmen und ernehren. Aber das Exempel, so man zu der zeit an diser Biesten gesehen, ist nie allein grösser, sonder auch etwas höher zu verwundern.

(19) In diser statt, sintemal sie auff einem solchen ort, da dieselbe Vögel füglich können gespeist werden, gelegen ist, kommen ihr järlich grosse Herden zusamen alda zu nisten.

(20) Nun hat sich aber dieser schädliche Brandt den dritten tag Maij erhaben, umb welche zeit die junge Störcklein schon zimlich erwachsen. Da haben viel leut gesehen und gemerckt, wie die alten, als sie vernommen, daß das Fewr schon an ire jungen und Nester reicht, sich erstlich höchlich beflossen, ire jungen auß dem Fewr beschützt, und letzlich, als wenn sie nicht länger leben wöllen dann jene, sich mit inen verbrennen lassen.

(21) Auß dieser statt war burtig der schandfleck David Jörg, der anfänger einer verfluchten Ketzerey, von welcher im Register weiter sol geredt werden.

(22) Man sol aber nicht meinen, daß diß diser statt zur schmach alhie geredt sey, sintemal sie dargegen viel ehrwirdige und wunder geschickte Männer herfür bracht, under welchen die vornembsten gewesen sind Aegidius der Poet, Joh. Grammaticus, und der vortrefflichste under allen, Jodocus Sasboutius, ein hochberümbter Doctor beider Rechten, welcher von keyser Carolo dem fünfften zum öbersten Richter in die Cantzeley zu Geldern gesetzt, auch ein vortrefflich guter Poet gewesen, und im selbst in seinen letzten tagen diß Epitaphium oder Grabschrift geschrieben, welche auch noch heutigs tags auff seinem Grabe, in der Haubtkirchen zu Arnheim gesehen wirt, und uns von wegen der schonheit und Gottsförchtigkeit, so darauß erscheinet, herzu zu 
schreiben gefallen.

(23) Siste gradum: quod es, ipse fui, fortaßis eris cras

Quod sum, cadauer putridum.

Olim Iodocus eram Sasbout: me misit in auras

Delfft, clara pars Batavia

Ter denis patrice causas decidimus annis,

Pars Consili haud ingloria,

Deinde\& pacatis prceses ius Coesare Gueldris

Dixi, iubente Carolo.

Quid tituli? quid opes? quid nunc prudentia prodest?

Mors summa miscet inferis.

Sola manet virtus homini post funera, solam,

Dum vivis, hanc cema.

(24) Es hat auch diese statt under andern gelehten Männern den Cornelium Musium an tag gebracht, welcher ein Abt deß Frawenclosters S. Agathæ gewesen, ein frommer auffrichtiger Mann, deßgleichen man wenig findt, ein gelehter Theologus, guter Poet, und zu dieser under betrübter zeit ein warer Märterer Gottes.

French text

\section{DELFT}

(1) DELFT, Ville tresfameuse d'Hollande, a le second lieu entre les Estats d'Hollande, prennant son nom en langaige commun du grand nombre des fossez de la Muese. Car DELFVEN signifie fouir \& faire une fossee.

(2) Elle est distante de Rotterdam, lieu de naissance de ce tresdoct Erasme, deux lieues, \& une du villaige appellè SGRAVEN HAGHE, qui est le plusgrand \& plusbeau de l'Europe.

(3) Elle fut iadis fundee par Godefroy Ducq de Loraine, surnommè Bossu, l'An de salut M.LXXV: y edifiant ung Chasteau, au quel il demeuroir, duquel a present n'y a aulcune memoire. Lequel apres auoir par l'espace de quattre ans tenu par force la Contè d'Hollande, fut vaincu \& expulsè de Theodore cincquiesme de ce nom, Contelegittime d'Hollande, \& finablement tuè en Anuers d'ung dart, comme on dict.

(4) La ville est peuplee \& riche, enuironnee de muraille forte, \& boulreuerts, auecq une closture de hayes en façon de rets, seruants d'aultre muraille, \& d'ung fossè d'eaue, si large qu'ung homme bien robust nescauroit iecter une pierre oultre icelle:

(5) ayant dedens la ville plusieurs canaulx \& fossez d'eaue, a grande commodite des bourgeois. Par ou, comme toutte l'Hollande est en admiration aux estrangiers, pour la curiosite \& nettete en leurs maisons \& mesnaige: ainsi sont ceulx de ceste ville, a la reste du paijs.

(6) Car plusgrande y est la pluye, tanty sont plusnettes les rues \& carrefours, pour la bonnen ordonnance: Car l'eaue de pluye emporte touttes les ordures par les canaulx ad ce commodieusement construicts. Dont le contraire aduient communement aux aultres villes: ou, tant plusgrande est la pluye, tant y sont les rues plusordes.

(7) Les habitans sont singulierement courtoiz \& netz, s'exerceants en toutte sorte de marchandise, \& principalement de Draperie, \& brassent ceruoise fort bonne, laquelle ilz transportent en lieux bien esloingez: lequel mestier (ou pour mieulx dire negotiation) les faict tresriches. 
(8) Les edifices tant publicqz que priuez y sont sumptueuz.

(9) Et pour commencer des lieux sacrez: l'Eglise principale, y appellee, la nouuelle, fundee l'an de Grace M.CCC.LVI, magnifique \& belle, dediee a S. Ursule, se voit de bien loing, pour la belle \& treshaulte tour: ornee de painctures singulieres, des painctres plusfameus: asscauoir d'Hemskercke, François Floris, Anthoine Blockland, \& de Pierre surnommè le Long.

(10) L'Eglise ancienne dediee a S. Hippolyte est aussi fort ornee de painctures \& tableaux dudict Hemskercke, \& de Maistre Iean Schore, iadis Chanoine d'Utrecht, duquel on trouue plusieurs oeuures \& painctures excellentes per toutte l'Hollande. (11) Mais que diray-ie du Cloistree de Saincte Agathe? Car ne la magnificence des structures \& bastimens (car les Princes y ont souuentesfois logè) ne les richesses du reuenu annuel, ne aussi les ornemens interieurs de l'Eglise, polroient estre recitez selon leur merites. Car l'Eglise de cestes Religieuses estoit quasi vestue \& couuerte dedens par tout, de pictures exquises, pour la grande affection que porterentay-dict lieu, Musius Poete tresfameus, Recteur tresuiigilant dudict Cloistre, \& Hemskercke bourgeois d'Harlem painctre trescelebre.

(12) Le marchè de la ville est grand \& large: au costè du Leuant duquel est l'Eglise principale, \& a l'opposite, la maison de la ville, auecq une tour treshaulte, en laquelle y a ung accord de cloches, sur lequel on ioue \& bastele au temps de quelques nopces de personnes de qualite, \& aux foires hebdommadales: duquel, comme se resiouissent les inuitez aux nopces, ainsi en sont tirez les marchants \& aultres au marchè.

(13) Aux fauxbourgs s'exerce toutte sorte de marchandise. Les maisons sont belles \& les hostelleries grandes, ou les estrangiers \& hostes sont bien recueillez \& traictez, s'ilz sont bien furniz d'argent.

(14) Et ce en brief de ceulx de Delft, en temps de pais \& prosperite.

(15) Mais commeau monde toutte chose est muable, elle a eu aussi sa part des guerres \& desgastz du feu, dont ella a parfois este deformee.

(16) Car estant assiegee par Albert de Bauieres Conte XXVI d'Hollande, fut priuee de ses preuileges \& murailles. Lesquelz leur furent tost apres renduz par le Conte Guillame de Bauieres son successeur, pour la victoire qu'il obtint contre les Frisons par leur assistence.

(17) Elle a sort gastee du feu l'an M.LXXXVI ${ }^{* * *}$ au mois de May le iour de la Saincte Croix apres disner. Car le feu y venant a l'impourueu, brusla les deux Eglises parochielles, la nouuelle \& vielle, les hospitaulx, \& plus de Mil deux Cents maisons, y demeurant a grand peine la cincquiesme part de la dicte ville entiere.

(18) Auquel feu aduint vne chose merueilleuse: laquelle ne de ceulx de nostre temps, ne ceulx qui ont du passè descript \& obseruè les choses naturelles, ont obseruè. Plinius, \& aultres Autheurs de renom, ont bien escript \& laissè a la posterite pour chose grande \& digne d'admiration (comme vrayement elle est) que les ieunes Cicognes nourrissent leurs parens, desaillans par viellesse, \& ne se scaçans bonnement a yder: mais lors fut ausdicts animaulx obseruee chose plusmerueilleuse, \& digne d'estre notee.

(19) En ceste ville (comme lieu fort idoine \& commode a nourrir ces oiseaulx) viennent annuellement plusieurs trouppes d'iceulx faire leurs nids.

(20) Et comme ceste calamite \& feu aduint le troisiesme de May, quand les petittes Cicognes commencent estre grandes, fut veu \& observuè de plusieurs, que les meres (voyans le feu approcher de leurs nids \& petits) sisrent extreme debuoir de porter leurs petits hors des flammes. Mais comme elles ne le scuerent faire pour leur grandeur \& pesanteur, se sont mises a les couurir de leurs ailes, \& les gsarder de feu \& flamme, si 
long tempes que leur fut possible. A la parfin se sont laissees brusler auecq iceulx, comme s'elles n'oeussent voulu viure apres eulx.

(21) De ceste ville estoit natif ce detestable Dauid George, Autheur d'vne secte abominable: de laquelle sera plus dict en la Table.

(22) Ce que ne diz en mesprisement de ceste ville: car d'icelle sont pereillement natifs plusieurs personnagtes honnorables: desquelz sont este Aegidius Poeta \& Ioannes Grammaticus, Monsieur Maistre Iosse Sasbout, Docteur tresfameus es Droicts, constitue par l'Empereur Charles cincquiesma Chancelier de Gelres, Poete treselegant: lequel se voyant approcher a la mort, a de foy mesme escript cest Epithaphe, lequel se voit encoires a sa sepulture, en l'Eglise principale de la ville d'Arnhem, mis icy pour sa piete \& elegance:

(23) Siste gradum: quod es, ipse sui, fortassis eris cras

Quod sum, cadauer putridum.

Olim Iodocus eram Sasbout: me misit in auras

Delft, clara pars Batavioe.

Ter denis patrice causas decidimus annis,

Pars Consili haud ingloria,

Deinde \& pacatis Prceses ius Coesare Gueldris

Dixi, iubente Carolo.

Quid tituli? quid opes? quid nunc prudentice prodest?

Mors summa miscet inferis.

Sola manet virtus homini post funera, solam,

Dum vivis, hanc œma.

(24) La mesme ville a aussi aultres produict Cornelium Musium, Recteur des Religieuses de S. Agathe, homme de modestie rare, Theologien excellent, \& Poete tresfameus, \& vray Martyr de Dieu en ce nostre temps tresmalheureus.

* Printing error, also in Latin text, M LXXXVI [1086] instead of M DXXXVI [1536].

${ }^{* *}$ Erroneous, printing error in the Latin text M LXXXVI [1086] instead of M DXXXVI

[1536].

${ }^{* * *}$ Printing error, M LXXXVI [1086] instead of M DXXXVI [1536].

\section{NOTES}

1. TOOLEY R.V. (1966), "Preface" to Mirror of the World, a series of early books on the history of urbanization, Braun \& Hogenberg Civitates Orbis Terrarum with an introduction by R.A. Skelton, Cleveland \& New York.

2. VAN DER KROGT P. (1998), “The Theatrum Orbis Terrarum: The first atlas?" in Abraham Ortelius and the first atlas: Essays commemorating the Quadricentennial of his Death, 1598-1998, edited by Marcel van den Broecke, Peter van der Krogt, Peter Meurer, pp. 55-78. 't Goy-Houten: HES Publishers.

3. VAN DER KROGT P., Koeman's Atlantes Neerlandici IV: The Town Atlases, 't Goy-Houten, HES \& De Graaf. (Forthcoming). This article is based on the research for this volume.

4. GUICCIARDINI L. (1567), La description de touts les Païs Bas, Antwerp, Silvius. 


\section{ABSTRACTS}

The Civitates orbis terrarum or the "Braun \& Hogenberg", published in six volumes in Cologne between 1572 and 1617, is the most famous of the early town atlases. Although it had no comparable precedent, it immediately answered a great public demand, because social, political and economic life at that time was concentrated in the cities.

Apart from that, the pictorial style of the plans and views appealed very much to the uneducated public.

Each of the six volumes is a distinct entity, containing plans of towns of the whole of Europe (and sometimes also of towns outside Europe). When a more recent plan of a town was acquired, it was included in one of the later volumes without changing the contents of the earlier volume. In fact, the contents of a volume has never been changed at all. The authors of the work are Georg Braun (Bruin), Frans Hogenberg and Simon van den Neuvel (Novellanus).

This paper discusses the choice of towns depicted and the distribution of these towns in Europe, the way the towns were depicted (plan, bird's-eye view, profile, landscape) and the information text given on the towns.

Le Civitates orbis terrarum ou "Braun \& Hogenberg", publié en six volumes entre 1572 et 1617 à Cologne, est le plus connu des premiers atlas des villes. Bien que sans précédent comparable, il répondait d'emblée à une large demande du fait qu'à cette époque la vie sociale, politique et économique se trouvait concentrée dans les villes.

En outre, le style imagé des plans et des illustrations plaisait beaucoup au grand public.

Chacun des six volumes est une entité distincte présentant des plans de villes situées dans l'ensemble de l'Europe (et parfois même hors d'Europe). Lorsqu'un plan plus récent d'une ville était réalisé, il était inclus dans un des volumes ultérieurs sans changement du contenu du volume précédent. En fait, le contenu d'un volume n'a jamais été modifié d'aucune façon. Les auteurs en sont Georg Braun (Bruin), Frans Hogenberg et Simon van den Neuvel (Novellanus).

Cet article étudie le choix des villes décrites ainsi que la répartition de ces villes en Europe, la façon dont les villes ont été décrites (plans, vue d'ensemble, profil, paysage), ainsi que les informations données à leur sujet.

\section{INDEX}

Mots-clés: atlas, plans de villes, histoire de la cartographie

Keywords: atlases, town plans, history of cartography

\section{AUTHOR}

\section{PETER VAN DER KROGT}

University of Utrecht, Faculty of Geo- Sciences, p.vanderkrogt@geo.uu.nl 